\title{
Picolinic acid spray stimulates the antioxidative metabolism and minimizes impairments on photosynthesis on wheat leaves infected by Pyricularia oryzae
}

\author{
Carlos Eduardo Aucique-Pérez ${ }^{a, b}$, Renata Sousa Resende ${ }^{a}$, Lara Beatriz Cruz Neto \\ Fernanda Dornelas ${ }^{a}$, Fábio Murilo DaMattab and Fabrício Ávila Rodrigues ${ }^{a}$, *(i) \\ aDepartment of Plant Pathology, Laboratory of Host-Pathogen Interaction, Universidade Federal de Viçosa (UFV), Viçosa, 36570-900, Brazil \\ ${ }^{b}$ Department of Plant Biology, Universidade Federal de Viçosa (UFV), Viçosa, 36570-900, Brazil
}

\section{Correspondence \\ *Corresponding author, \\ e-mail: fabricio@ufv.br}

Received 12 December 2018

doi:10.1111/ppl.12917
Fungal pathogens produce toxins that are important for their pathogenesis and/or aggressiveness towards their hosts. Picolinic acid (PA), a non-host selective toxin, causes lesions on rice leaves resembling those originated from Pyricularia oryzae infection. Considering that non-host selective toxins can be useful for plant diseases control, this study investigated whether the foliar spray with PA on wheat (Triticum aestivum L.) plants, in a non-phytotoxic concentration, could increase their resistance to blast, stimulate the anti-oxidative metabolism, and minimize alterations in photosynthesis. The PA spray at concentrations greater than $0.1 \mathrm{mg} \mathrm{ml}^{-1}$ caused foliar lesions, compromised the photosynthesis and was linked with greater accumulation of hydrogen peroxide $\left(\mathrm{H}_{2} \mathrm{O}_{2}\right)$ and superoxide anion radical $\left(\mathrm{O}_{2}{ }^{\bullet-}\right)$. Fungal mycelial growth, conidia production and germination decreased by PA at $0.3 \mathrm{mg} \mathrm{m}^{-1}$. Blast severity was significantly reduced by 59 and $23 \%$, respectively, at 72 and $96 \mathrm{~h}$ after inoculation for plants sprayed with PA $\left(0.1 \mathrm{mg} \mathrm{ml}^{-1}\right)$ at $24 \mathrm{~h}$ before fungal inoculation compared to non-sprayed plants. Reduction on blast symptoms was linked with increases on ascorbate peroxidase (EC 1.11.1.11), catalase (EC 1.11.1.6), glutathione peroxidase (EC 1.11.1.9), glutathione reductase (EC 1.8.1.7), glutathione-S-transferase (EC 2.5.1.18), peroxidase (EC 1.11.1.7), and superoxide dismutase (EC 1.15.1.1) activities, lower $\mathrm{H}_{2} \mathrm{O}_{2}$ and $\mathrm{O}_{2}{ }^{\bullet-}$ accumulation, reduced malondialdehyde production as well as less impairments to the photosynthetic apparatus. A more efficient antioxidative metabolism that rapidly scavenges the reactive oxygen species generated during $P$. oryzae infection, without dramatically decreasing the photosynthetic performance, was a remarkable effect obtained with PA spray.

Abbreviations - $A$, net $\mathrm{CO}_{2}$ assimilation rate; $\mathrm{APX}$, ascorbate peroxidase; $\mathrm{BS}$, blast severity; $C A T$, catalase; $C_{\mathrm{i}}$, internal $\mathrm{CO}_{2}$ concentration; $E$, transpiration rate; $F_{m}$, maximum fluorescence image; $F_{\mathrm{v}} / F_{\mathrm{m}}$, variable-to-maximum chlorophyll fluorescence ratio; GPX, glutathione peroxidase; $g_{s}$, stomatal conductance to water vapor; GST, glutathione-S-transferase; hai, hours after inoculation; $\mathrm{H}_{2} \mathrm{O}_{2}$, hydrogen peroxide; MDA, malondialdehyde; $\mathrm{O}_{2}{ }^{--}$, superoxide anion radical; $\mathrm{PA}$, picolinic acid; $\mathrm{POX}$, peroxidase; $q_{\mathrm{p}}$, coefficient for photochemical quenching; SOD, superoxide dismutase; $Y(I I)$, effective photosystem II quantum yield; $Y(N O)$, quantum yield of non-regulated energy dissipation; $Y(N P Q)$, quantum yield of regulated energy dissipation. 


\section{Introduction}

Blast, caused by the fungus Pyricularia oryzae Cavara (teleomorph Magnaporthe grisea [T. T. Hebert] M. E. Barr), was first reported on wheat (Triticum aestivum L.) in 1985 in Paraná State, Brazil (Igarashi et al. 1986). Since then, blast has caused significant yield losses (up to $60 \%$ ) on commercial wheat fields in Argentina, Bolivia, Brazil and Paraguay when weather conditions are favorable such as rainy periods, high relative humidity and temperatures ranging from 21 to $27^{\circ} \mathrm{C}$ (Goulart et al. 2007, Kohli et al. 2011). In 2016, wheat blast was reported in eight districts in Bangladesh, southwestern Asia, affecting about $16 \%$ of the cultivated area in this country (Malaker et al. 2016). It is evident that conidia dispersion of $P$. oryzae to other continents is a real problem that may put wheat production at risk.

On wheat leaves, the first blast symptoms appear at 48 hours after inoculation (hai) as small water-soaked lesions which quickly expand and exhibit dark green borders that become light tan in color with necrotic borders (Igarashi et al. 1986, Goulart et al. 2007, Cruz et al. 2016). Gray-brown lesions are noticed on both spikes and spikelets and bright black spots on the rachis (Goulart et al. 2007). The foliar application of systemic fungicides and the use of resistant cultivars have contributed to some extent to blast control on wheat (Cruz et al. 2010, Castroagudín et al. 2015, Rios et al. 2016).

The infection process of pathogens is favored by the intensive production of both hydrolytic enzymes and toxins at the infection sites (Willis et al. 1991, Howlett 2006). Toxins, named as host- and non-host selective, are molecules of low molecular weight with a high structural diversity originated from the primary metabolism of necrotrophic and hemibiotrophic fungal pathogens (Howlett 2006, Berestetski 2008). Perturbations caused by toxins on plant physiology include the suppression of cell division, inhibition of photosynthesis photochemistry, changes on the primary and secondary metabolism, increased production of reactive oxygen species (ROS), loss of cellular homeostasis and damage of the cell membranes that will ultimately cause cell death (Berestetski 2008, Dong et al. 2012, Chen et al. 2014). Pathogens producing host-selective toxins cause diseases only on the hosts unable to detoxify them while the non-host selective toxins maximize, together with the hydrolytic enzymes, the intensity of the diseases (Wheeler and Luke 1963, Wolpert et al. 2002, Tsuge et al. 2013). The non-host selective toxins pyricularin, pyriculol-related compounds (e.g. epipyriculol, epidihydropyriculol, pyriculariol and pyricuol), tenuazonic acid and picolinic acid (PA) were produced by P. oryzae on rice leaves (Kim et al. 1998, Tsurushima et al. 2010). The tenuazonic acid, PA and pyriculol are of greater importance for blast symptoms development on rice (Umetsu et al. 1972, Yoder 1980, Iwahashi et al. 1999, Jacob et al. 2016).

The use of non-host selective toxins can be of some value at aiming disease control. The non-host selective is used in plant breeding programs to avoid the uneven exposure to the pathogen and improving the selection processes (Daub 1986). The spray of PA to rice callus culture of different cultivars allowed the selection of genotypes with resistance to blast (Prabhu and Rush 1997). The spray of rice leaves with tenuazonic acid and picolinic acid inhibited hyphae growth of $P$. oryzae on leaf tissues due to a high production of ROS (Pasechnik et al. 1993, Zhang et al. 2004, Aver'yanov et al. 2007). Rice resistance to blast mediated by PA spray was associated with an increase on NADPH oxidase activity, a rapid increased of $\mathrm{H}_{2} \mathrm{O}_{2}$ pools and the accumulation of transcripts of defense-related genes (Zhang et al. 2004).

Considering the potential of using a non-host selective toxin to increase host resistance to disease, this study aimed to test the hypothesis that wheat plants sprayed with PA in a non-phytotoxic concentration could increase their resistance to blast through a better adjustment of the antioxidant metabolism accompanied by the preservation of the photosynthetic capacity of the infected plants.

\section{Materials and methods}

\section{Plant growth}

Wheat seeds (cultivar BRS-Guamirim; susceptible to blast) (Cruz et al. 2010) were surface-sterilized in $10 \%(\mathrm{v} / \mathrm{v}) \mathrm{NaOCl}$ for $2 \mathrm{~min}$, rinsed in sterilized water for $3 \mathrm{~min}$ and germinated on plastic pots (20-cm diameter) filled with $1 \mathrm{~kg}$ of substrate made from a 1:1:1 mixture of pine bark, peat and expanded vermiculite (Tropstrato, Vida Verde, Mogi Mirim, SP, Brazil). A total of $1.63 \mathrm{~g}$ of calcium phosphate monobasic was added to each plastic pot. A total of nine seeds were sown per pot and at 8 days after seedlings emergence, each pot was thinned to six seedlings. Substrate in each pot was fertilized with a nutrient solution containing, in gram per liter, $6.4 \mathrm{KCl}, 3.48 \mathrm{~K}_{2} \mathrm{SO}_{4}, 5.01 \mathrm{MgSO}_{4} \bullet 7 \mathrm{H}_{2} \mathrm{O}$, $2.03\left(\mathrm{NH}_{2}\right)_{2} \mathrm{CO}, \quad 0.009 \quad \mathrm{NH}_{4} \mathrm{MO}_{7} \mathrm{O}_{24} \bullet 4 \mathrm{H}_{2} \mathrm{O}, 0.054$ $\mathrm{H}_{3} \mathrm{BO}_{3}, \quad 0.222 \quad \mathrm{ZnSO}_{4} \bullet 7 \mathrm{H}_{2} \mathrm{O}, 0.058 \quad \mathrm{CuSO}_{4} \bullet 5 \mathrm{H}_{2} \mathrm{O}$ and $0.137 \mathrm{MnCl}_{2} \bullet 4 \mathrm{H}_{2} \mathrm{O}$ (Xavier-Filha et al. 2011). A volume of $15 \mathrm{ml}$ of nutrient solution containing $0.27 \mathrm{~g}$ of $\mathrm{FeSO}_{4} \bullet 7 \mathrm{H}_{2} \mathrm{O}$ and $0.37 \mathrm{~g}$ of EDTA bisodic $\mathrm{I}^{-1}$ was 
also applied after seedlings emergence. The nutrient solutions were prepared using deionized water and applied weekly. Plants were watered with deionized water as needed.

\section{Effect of PA spray on the photosynthetic performance of plants}

Wheat plants (35 days after emergence; growth stage 39) (Lancashire et al. 1991) were sprayed with PA solutions at the concentrations of $0,0.1,0.3,0.5,1.0,1.5,3.0$ and $5.0 \mathrm{mg} \mathrm{ml}^{-1}$. The leaf gas exchange parameters net $\mathrm{CO}_{2}$ assimilation rate $(A)$, stomatal conductance to water vapor $\left(g_{\mathrm{s}}\right)$, internal $\mathrm{CO}_{2}$ concentration $\left(C_{\mathrm{i}}\right)$ and transpiration rate $(E)$ were measured using a portable open-flow gas exchange system (LI-6400XT; Li-Cor Inc.). Measurements, performed at 24 and $48 \mathrm{~h}$ after PA spray, were made at the attached fourth leaf, from the top to the base, of each plant per replication of each treatment from 09:00 to 11:00 h (solar time) when A was at its maximum. The experimental conditions during measurements were: artificial photosynthetically active radiation (PAR) of $1000 \mu \mathrm{mol}$ photons $\mathrm{m}^{-2} \mathrm{~s}^{-1}$ at the leaf level; $400 \mu$ mol atmospheric $\mathrm{CO}_{2} \mathrm{~mol}^{-1}$ air; $25^{\circ} \mathrm{C}$; vapor pressure deficit at approximately $1.0 \mathrm{kPa}$; and $10 \%$ of blue light (relative to total PAR) to optimize the stomatal aperture.

The imaging of the chlorophyll (Chl) a fluorescence parameters were determined by using the Imaging-PAM MAXI chlorophyll fluorometer and the software ImagingWIN (version 2.32) (Heinz Walz GmbH). The sensor system consisted of 44 LED's lamp high power $(450 \mathrm{~nm})$ required to apply fluorescence excitation, actinic illumination and saturation pulses. These LEDs were arranged in pairs, with each pair featuring a red $(660 \mathrm{~nm})$ and a near-infrared $(780 \mathrm{~nm})$ LED. A CCD camera with $640 \times 480$ resolution pixels was located above the plant canopies at a distance of $13.5 \mathrm{~cm}$ to give an image area of $10 \times 13 \mathrm{~cm}$. Plants from the different experiments were adapted to darkness for $45 \mathrm{~min}$ (Baker 2008) and the minimum fluorescence image $\left(F_{0}\right)$ was obtained from the fourth leaf, from the top to the base, of each plant per replication of treatment after being exposed to a light pulse intensity of $0.5 \mu \mathrm{mol} \mathrm{m}^{-2} \mathrm{~s}^{-1}$ $(1 \mathrm{~Hz})$ at 24 and $48 \mathrm{~h}$ after spray the eight PA solutions. Next, a saturating pulse of blue light $(470 \mathrm{~nm})$ of $2400 \mu \mathrm{mol} \mathrm{m}^{-2} \mathrm{~s}^{-1}$ intensity $(10 \mathrm{~Hz})$ was delivered at $0.8 \mathrm{~s}$ in order to obtain the maximum fluorescence image $\left(F_{\mathrm{m}}\right)$. The software performed the calculation and image of the maximum photosystem (PS) II photochemical efficiency $\left(F_{\mathrm{v}} / F_{\mathrm{m}}=\left(F_{\mathrm{m}}-F_{0}\right) / F_{\mathrm{m}}\right)$, which denotes the maximum PS II quantum efficiency (Baker 2008). Leaves were subsequently exposed to actinic photon irradiance $\left(110 \mu \mathrm{mol} \mathrm{m} \mathrm{m}^{-2} \mathrm{~s}^{-1}\right)$ for $300 \mathrm{~s}$ to obtain the steady-state fluorescence yield $\left(F_{\mathrm{s}}\right)$, after which a saturating white light pulse $\left(2400 \mu \mathrm{mol} \mathrm{m}^{-2} \mathrm{~s}^{-1} ; 0.8 \mathrm{~s}\right)$ was applied to achieve the light-adapted maximum fluorescence $\left(F_{\mathrm{m}}{ }^{\prime}\right)$. The light-adapted initial fluorescence $\left(F_{0}{ }^{\prime}\right)$ was estimated according to Oxborough and Baker (1997). Following Kramer et al. (2004), the energy absorbed by PSII for the following three yield components for dissipative processes was determined: the effective PSII quantum yield $\left.\left[\mathrm{Y}(\mathrm{II})=\left(F_{\mathrm{m}}{ }^{\prime}-F_{\mathrm{s}}\right) / F_{\mathrm{m}}{ }^{\prime}\right)\right]$, the quantum yield of regulated energy dissipation $\left[\mathrm{Y}(\mathrm{NPQ})=\left(F_{\mathrm{s}} / F_{\mathrm{m}}{ }^{\prime}\right)-\left(F_{\mathrm{s}} / F_{\mathrm{m}}\right)\right]$, and the quantum yield of non-regulated energy dissipation $\left[\mathrm{Y}(\mathrm{NO})=F_{\mathrm{s}} / F_{\mathrm{m}}\right]$; additionally, the coefficient of photochemical quenching, as $q_{\mathrm{p}}=\left(F_{\mathrm{m}}{ }^{\prime}-F\right) /\left(F_{\mathrm{m}}{ }^{\prime}-F_{0}{ }^{\prime}\right)$, was also calculated. For semi-quantitative analyses of $\mathrm{Chl}$ a fluorescence parameters, a total of five areas of interest $\left(1 \mathrm{~cm}^{2}\right.$ each) were randomly selected in each leaf of plant per replication of each treatment at 24 and $48 \mathrm{~h}$ after spray the PA solutions.

\section{Histochemical localization of hydrogen peroxide $\left(\mathrm{H}_{2} \mathrm{O}_{2}\right)$ and superoxide anion radical $\left(\mathrm{O}_{2}{ }^{\circ-}\right)$ on PA sprayed leaves}

Fifteen fragments $(\sim 10 \mathrm{~cm}$ of length) of the fourth and fifth leaves, from top to base, of each plant per replication of each treatment, were collected at $24 \mathrm{~h}$ after PA spray were used. For detection of $\mathrm{H}_{2} \mathrm{O}_{2}$, fragments were placed in glass vials containing a solution of 3, $3^{\prime}$-diaminobenzidine tetrahydrochloride $\left(1 \mathrm{mg} \mathrm{ml}^{-1}\right)$ (Sigma-Aldrich), kept in the dark at $25^{\circ} \mathrm{C}$ for $12 \mathrm{~h}$, cleared in boiling aqueous $80 \%$ ethanol for $60 \mathrm{~min}$ thereafter and stored in glycerol solution $(70 \%)$. For detection of $\mathrm{O}_{2}{ }^{\bullet-}$, leaf fragments placed in glass vials were infiltrated with a solution of $0.1 \%$ nitro blue tetrazolium (Sigma-Aldrich) in $10 \mathrm{mM}$ potassium phosphate buffer ( $\mathrm{pH}$ 6.8) for $40 \mathrm{~min}$, and then cleared and stored as described above.

\section{The in vitro effect of PA on fungal mycelial growth, conidia production and germination}

The sensitivity of $P$. oryzae to PA was evaluated in vitro using PA at eight concentrations of $0,0.1,0.3,0.5,1.0$, $1.5,3.0$ and $5.0 \mathrm{mg} \mathrm{ml}^{-1}$. The PA solutions were incorporated into the potato-dextrose-agar (PDA) medium and then poured into Petri dishes ( $20 \mathrm{ml}$ per plate). After $4 \mathrm{~h}$, one PDA plug ( $5 \mathrm{~mm}$ in diameter), containing fungal mycelia obtained from the edge of a 10-day-old $P$. oryzae colony, was placed in the central region of each Petri dish, which were kept in a growth chamber $\left(25^{\circ} \mathrm{C}\right.$ and $12 \mathrm{~h}$ photoperiod). At 7 days, fungal colony in each Petri dish was measured in two orthogonal directions using 
a digital paquimeter to obtain its diameter. At this time, conidia production in each Petri dish containing only oat-agar (OA) medium with the concentrations of $0,0.1$ and $0.3 \mathrm{mg} \mathrm{PA} \mathrm{ml}{ }^{-1}$ was determined. A total of $20 \mathrm{ml}$ of sterile distilled water was added to each Petri dish and conidia were carefully disrupted using a camel-hair brush inside a laminar flow chamber. Conidia concentration was quantified in $500 \mu \mathrm{l}$ of suspension per each treatment using a hemacytometer.

Conidia obtained from a 10-day-old colonies of $P$. oryzae in Petri dishes containing OA medium were removed using a camel-hair brush to obtain a conidial suspension of $1 \times 10^{5}$ conidia ml-1. A total of $10 \mu \mathrm{l}$ of conidial suspension was transferred to five Petri dishes containing $\mathrm{OA}$ with the concentrations of $0,0.1$ and $0.3 \mathrm{mg} \mathrm{PA} \mathrm{ml} \mathrm{m}^{-1}$ and was homogeneously distributed on each dish using a Drigalski glass stick to determine the PA effect on conidia germination. Petri dishes were transferred to a growth chamber at $25^{\circ} \mathrm{C}$. After $4 \mathrm{~h}$, lactophenol was added to the plates to stop conidia germination. Two hundred conidia were randomly examined from each Petri dish under a microscope (Carl Zeiss Axiolmager A1) at $\times 40$ magnification. A conidium was considered germinated when the germ tube was longer than its diameter and the percentage of germination was calculated.

\section{Inoculum production, PA spray and plant inoculation with $P$. oryzae}

Plants were inoculated with the isolate UFV/DFP $P_{O}-01$ of $P$. oryzae (Debona et al. 2012). Disks of filter paper containing fungal mycelia were transferred to Petri dishes containing OA medium. After growing the disks containing mycelia, the media with the fungus were transferred to new Petri dishes with the same medium. The dishes were incubated in a growth chamber at $25^{\circ} \mathrm{C}$ with a $24 \mathrm{~h}$ photoperiod for 10 days. After this period, conidia were carefully removed from the Petri dishes with a soft bristle brush using water containing gelatin $(1 \% \mathrm{w} / \mathrm{v})$. The conidial suspension was calibrated with a hemacytometer to obtain a concentration of $1 \times 10^{5}$ conidia $\mathrm{ml}^{-1}$. At $24 \mathrm{~h}$ before inoculation, plants were sprayed with a solution of $0.1 \mathrm{mg} \mathrm{PA} \mathrm{ml}^{-1}$ ( $35 \mathrm{ml}$ per plant), which was selected based on a preliminary experiment that determined the effect of PA at different concentrations on the plant photosynthetic performance. The conidial suspension was sprayed with an atomizer (Paasche Airbrush Co.) on the adaxial surface of the leaves of plants at growth stage 39. After inoculation, plants were kept in a mist chamber under darkness at $25^{\circ} \mathrm{C}$ during $24 \mathrm{~h}$ and transferred to a greenhouse (relative humidity of $80 \pm 5 \%$, temperature of $25 \pm 3^{\circ} \mathrm{C}$ and natural PAR of $900 \mu \mathrm{mol}$ photons $\mathrm{m}^{-2} \mathrm{~s}^{-1}$ as measured at midday) thereafter.

\section{Blast severity assessment}

Blast severity (BS) was evaluated on the fourth and fifth leaves, from top to base, of each plant per replication of each treatment, at 48, 72 and 96 hours after inoculation (hai) using a diagrammatic scale (Rios et al. 2013).

\section{Photosynthesis measurements and histochemical localization of $\mathrm{H}_{2} \mathrm{O}_{2}$ and $\mathrm{O}_{2}{ }^{--}$}

Leaf gas exchange and $\mathrm{Chl}$ a fluorescence parameters were measured on the attached fourth leaf, from top to base, of each plant per replication of each treatment as described above at 48, 72 and 96 hai. The histochemical localization of $\mathrm{H}_{2} \mathrm{O}_{2}$ and $\mathrm{O}_{2}{ }^{-}{ }^{-}$was performed at 24, 48 and 72 hai as previously described.

\section{Determination of enzyme activities}

The fourth and fifth leaves, from base to top, of each plant per replication of each treatment were collected at 48, 72 and 96 hai. Leaf samples were kept in liquid nitrogen during sampling and then stored at $-80^{\circ} \mathrm{C}$ until further analysis. For determination of the activities of ascorbate peroxidases (APX, EC 1.11.1.11), catalases (CAT, EC 1.11.1.6), peroxidases (POX, EC 1.11.1.7), superoxide dismutases (SOD, EC 1.15.1.1), glutathione peroxidases (GPX, EC 1.11.1.9) and glutathione-S-transferases (GST, EC 2.5.1.18), a total of $0.3 \mathrm{~g}$ of leaf tissue was ground into a fine powder in a mortar and pestle with liquid nitrogen. The fine powder was homogenized in an ice bath in $2 \mathrm{ml}$ of a solution containing $100 \mathrm{mM}$ potassium phosphate buffer ( $\mathrm{pH}$ 6.8), $0.1 \mathrm{mM}$ EDTA, $1 \mathrm{mM}$ phenylmethylsulfonyl fluoride (PMSF) and $2 \%\left(\mathrm{wt} \mathrm{vol}^{-1}\right.$ ) polyvinylpolypyrrolidone (PVPP). The homogenate was centrifuged at $12000 \mathrm{~g}$ for $15 \mathrm{~min}$ at $4^{\circ} \mathrm{C}$ and the supernatant was used as a crude enzyme extract. In order to determine the glutathione reductases (GR, EC 1.8.1.7) activity, a total of $0.3 \mathrm{~g}$ of leaf tissue was ground as described above. The fine powder was homogenized in an ice bath in $2 \mathrm{ml}$ of a solution containing $100 \mathrm{mM}$ potassium phosphate buffer (pH 7.5), $0.1 \mathrm{mM}$ EDTA, $1 \mathrm{mM}$ DL-dithiothreitol, $1 \mathrm{mM}$ PMSF and $2 \%\left(\mathrm{wt} \mathrm{vol}^{-1}\right.$ ) PVPP. The homogenate was centrifuged as described above.

The SOD activity was determined by measuring its ability to photochemically reduce the $p$-nitrotetrazole blue (NTB) (Del Longo et al. 1993). The reaction was started after the addition of $60 \mu \mathrm{l}$ of the crude enzyme extract to $1.94 \mathrm{ml}$ of a mixture containing $100 \mathrm{mM}$ potassium phosphate buffer $(\mathrm{pH} 7.8), 13 \mathrm{mM}$ methionine, 
$75 \mu \mathrm{M}$ NTB, $0.1 \mathrm{mM}$ EDTA and $2 \mu \mathrm{M}$ riboflavin. The reaction occurred at $25^{\circ} \mathrm{C}$ under a $15 \mathrm{~W}$ lamp light. After 10 min of light exposure, the light was turned off and the production of formazan blue, which resulted from the photoreduction of NTB, was monitored by the increase in absorbance at $560 \mathrm{~nm}$ in a spectrophotometer (Giannopolitis and Ries 1977). The reaction mixture for the control samples was kept in darkness. The values obtained were subtracted from the values obtained from the samples of the replications of each treatment exposed to light. One unit of SOD was defined as the amount of enzyme necessary to inhibit NBT photoreduction by 50\% (Beauchamp and Fridovich 1971).

The CAT activity was determined following Cakmak and Marschner (1992). The reaction mixture consisted of $100 \mathrm{mM}$ potassium phosphate buffer $(\mathrm{pH} \mathrm{6.8)}$ ) and $20 \mathrm{mM} \mathrm{H}_{2} \mathrm{O}_{2}$ in a volume of $1.95 \mathrm{ml}$. The reaction was initiated after the addition of $50 \mu \mathrm{l}$ of the crude enzyme extract and CAT activity was determined by the rate of $\mathrm{H}_{2} \mathrm{O}_{2}$ decomposition at $240 \mathrm{~nm}$ during $1 \mathrm{~min}$ at $25^{\circ} \mathrm{C}$. The extinction coefficient of $36 \mathrm{M}^{-1} \mathrm{~cm}^{-1}$ (Anderson et al. 1995) was used to calculate CAT activity, which was expressed as micromole per minute per milligram of protein.

The POX activity was assayed following the colorimetric determination of pyrogallol oxidation according to Kar and Mishra (1976). The reaction mixture contained $50 \mathrm{mM}$ potassium phosphate $(\mathrm{pH} 6.8), 20 \mathrm{mM}$ pyrogallol and $20 \mathrm{mM} \mathrm{H}_{2} \mathrm{O}_{2}$ in a volume of $1.98 \mathrm{ml}$. The reaction was started after the addition of $15 \mu \mathrm{l}$ of the crude enzyme extract and the POX activity was determined through the absorbance of colored purpurogallin recorded at $420 \mathrm{~nm}$ during $1 \mathrm{~min}$ at $25^{\circ} \mathrm{C}$. The extinction coefficient of $2.47 \mathrm{mM}^{-1} \mathrm{~cm}^{-1}$ (Chance and Maehley 1955) was used to calculate POX activity, which was expressed as millimole of purpurogallin produced per minute per milligram of protein.

The GST activity was determined using the methodology proposed by Habig et al. (1974). A total of $150 \mu \mathrm{l}$ of the crude enzyme extract was added to $1.35 \mathrm{ml}$ of the mixture containing $50 \mathrm{mM}$ potassium phosphate buffer $(\mathrm{pH} 6.5)$ and $50 \mathrm{mM}$ reduced glutathione (GSH). The reaction was initiated after the addition of $500 \mu \mathrm{l}$ of $30 \mathrm{mM}$ 1-chloro-2,4-dinitrobenzene and then incubated for $4 \mathrm{~min}$ at $25^{\circ} \mathrm{C}$. The absorbance was measured at $340 \mathrm{~nm}$ over $3 \mathrm{~min}$. The extinction coefficient of $9.6 \mathrm{mM}^{-1} \mathrm{~cm}^{-1}$ (Habig et al. 1974) was used to determine GST activity, which was expressed as micromole per minute per milligram of protein.

The APX activity was determined according to the method of Nakano and Asada (1981). The reaction mixture consisted of $50 \mathrm{mM}$ potassium phosphate buffer (pH 6.8), $1 \mathrm{mM} \mathrm{H}_{2} \mathrm{O}_{2}$ and $0.8 \mathrm{mM}$ ascorbate in a volume of $1.95 \mathrm{ml}$. The reaction was started after the addition of $50 \mu$ l of the crude enzyme extract. The APX activity was measured by the rate of ascorbate oxidation at $290 \mathrm{~nm}$ for $1 \mathrm{~min}$ at $25^{\circ} \mathrm{C}$. The extinction coefficient of $2.8 \mathrm{mM}^{-1} \mathrm{~cm}^{-1}$ (Nakano and Asada 1981) was used to calculate APX activity, which was expressed as micromole per minute per milligram of protein.

In order to determine GR activity, the reaction was started after the addition of $100 \mu \mathrm{l}$ of the crude enzyme extract to a volume of $1.9 \mathrm{ml}$ of a mixture containing $100 \mathrm{mM}$ potassium phosphate $(\mathrm{pH} 7.5), 1 \mathrm{mM}$ EDTA, $1 \mathrm{mM}$ oxidized glutathione (GSSG) and $0.1 \mathrm{mM} \mathrm{NADPH}$ prepared in $0.5 \mathrm{mM}$ Tris-HCl buffer $(\mathrm{pH} 7.5)$ according to Carlberg and Mannervik (1985). The decrease in absorbance was determined at $340 \mathrm{~nm}$ for $1 \mathrm{~min}$ at $30^{\circ} \mathrm{C}$. The extinction coefficient of $6.22 \mathrm{mM}^{-1} \mathrm{~cm}^{-1}$ (Foyer and Halliwell 1976) was used to calculate GR activity, which was expressed as micromole per minute per milligram of protein.

The GPX activity was estimated after the addition of $100 \mu$ l of the crude enzyme extract to a mixture containing $50 \mathrm{mM}$ potassium phosphate buffer $(\mathrm{pH} 7.0), 1 \mathrm{mM}$ EDTA, $0.114 \mathrm{M} \mathrm{NaCl}, 1 \mathrm{mM}$ GSH, $0.2 \mathrm{mM} \mathrm{NADPH}$, $0.25 \mathrm{mM} \mathrm{H}_{2} \mathrm{O}_{2}$ and $1 \mathrm{U}$ of GR (Nagalakshmi and Prasad 2001). The decrease in absorbance was measured at $340 \mathrm{~nm}$ for $1 \mathrm{~min}$ at $30^{\circ} \mathrm{C}$. The extinction coefficient of $6.22 \mathrm{mM}^{-1} \mathrm{~cm}^{-1}$ (Anderson and Davis 2004) was used to calculate GPX activity, which was expressed as micromole per minute per milligram of protein.

For each enzyme, four separate extractions were performed for samples from each treatment. Each extraction was read three times. A boiled extract was used as the blank treatment during enzyme activity determinations. The soluble protein concentration of each extract was measured according to Bradford (1976) using bovine serum albumin as the standard protein.

\section{Determination of malondialdehyde (MDA) concentration}

Oxidative damage in the leaf cells was estimated as the concentration of total 2-thiobarbituric acid (TBA) reactive substances and expressed as equivalents of MDA (Cakmak and Horst 1991). A total of $100 \mathrm{mg}$ of leaf tissue was ground into a fine powder using a mortar and pestle with liquid nitrogen. The fine powder was homogenized in $2 \mathrm{ml}$ of $0.1 \%$ (wt vol ${ }^{-1}$ ) trichloracetic acid (TCA) solution in an ice bath. The homogenate was centrifuged at $12000 \mathrm{~g}$ for $15 \mathrm{~min}$ at $4{ }^{\circ} \mathrm{C}$. After centrifugation, a total of $0.5 \mathrm{ml}$ of the supernatant was reacted with $1.5 \mathrm{ml}$ of TBA solution $(0.5 \%$ in $20 \%$ TCA) for $30 \mathrm{~min}$ in a boiling water bath at $95^{\circ} \mathrm{C}$. After this period, the reaction was stopped in an ice bath. The 
samples were centrifuged at $9000 \mathrm{~g}$ for $10 \mathrm{~min}$ and the specific absorbance was determined at $532 \mathrm{~nm}$. The nonspecific absorbance was estimated at $600 \mathrm{~nm}$ and subtracted from the specific absorbance value. The extinction coefficient of $155 \mathrm{mM}^{-1} \mathrm{~cm}^{-1}$ (Heath and Packer 1968) was used to calculate MDA concentration, which was expressed as nanomole per gram of fresh weight (FW).

\section{Experimental design and data analysis}

Seven experiments were carried out with different goals. Experiments 1 to 4 were arranged in a completely randomized design with at least five replications to determine the effect of PA concentrations on leaf gas exchange and $\mathrm{Chl}$ a fluorescence parameters (Exp. 1); on $\mathrm{H}_{2} \mathrm{O}_{2}$ and $\mathrm{O}_{2}{ }^{--}$production (Exp. 2); on fungal mycelial growth and conidia production (Exp. 3); and on conidia germination (Exp. 4). Experiments 5 to 7 were arranged in a completely randomized design with four treatments combinations [plants non-sprayed (-PA) or sprayed $(+\mathrm{PA})$ with $\mathrm{PA}$ and non-incoulated $\left(-\mathrm{PO}_{\mathrm{O}}\right.$ or inoculated $(+P O)$ with $P$. oryzae] (referred as $-\mathrm{PA} /-P_{O}$, $+\mathrm{PA} /-P_{\mathrm{O}},-\mathrm{PA} /+P_{O}$, and $+\mathrm{PA} /+P_{O}$ treatments thereafter) and five replications to determine the effect of a low concentration of PA $\left(0.1 \mathrm{mg} \mathrm{ml}^{-1}\right)$ on leaf gas exchange and $\mathrm{Chl}$ a fluorescence parameters (Exp. 5), on the production of $\mathrm{H}_{2} \mathrm{O}_{2}$ and $\mathrm{O}_{2}{ }^{\bullet-}$ in the leaf tissue (Exp. 6 ), and on biochemical variables (MDA concentration and APX, CAT, GPX, GR, GST, POX and SOD activities). All of these experiments were repeated once. Each experimental unit corresponded to a plastic pot containing six plants. Data obtained from Exps 1 to 7 were analyzed using the MIXED procedure of the SAS software (Release 8.02 Level 02M0 for Windows, SAS Institute, Inc., 1989, Cary, NC) to determine if data from the repeated experiments could be combined (Moore and Dixon, 2015). Data from all variables and parameters were analyzed using ANOVA and treatments mean were compared either with F, Dunnet or Tukey tests $(P \leq 0.05)$ using SAS (version 6.12; SAS Institute, Inc.). Principal components analysis (PCA) technique was used to determine the relationship among the variables evaluated on Exps 5 and 7. Data were analyzed using the Minitab software (version 15; Minitab Corporation).

\section{Results}

\section{Effect of different PA concentrations on leaf gas exchange and $\mathrm{Chl}$ a fluorescence parameters}

Above $0.1 \mathrm{mg} \mathrm{PA} \mathrm{ml}^{-1}$, the $A$ values decreased significantly with increasing PA concentrations and were $52 \%$ lower at the highest concentration $\left(5.0 \mathrm{mg} \mathrm{PA} \mathrm{ml}^{-1}\right.$ ) than at 0 or $0.1 \mathrm{mg} \mathrm{PA} \mathrm{ml}^{-1}$ (Fig. $1 \mathrm{~A}$ ). Similar decreases for $g_{\mathrm{s}}$ (Fig. 1B) and $E$ (Fig. 1C), observed at concentrations above $0.3 \mathrm{mg} \mathrm{PA} \mathrm{ml}^{-1}$, were also found; at $5.0 \mathrm{mg}$ PA ml ${ }^{-1}$ both $g_{\mathrm{s}}$ and $E$ values were $53 \%$ lower than those of control plants. At the concentrations of 3.0 and $5.0 \mathrm{mg} \mathrm{PA} \mathrm{ml}^{-1}$, significant decreases in both $F_{\mathrm{v}} / F_{\mathrm{m}}$ $(9-11 \%)$ and $q_{\mathrm{P}}(10-18 \%)$ (Fig. 1D,E) were coupled with significant increases in $\mathrm{Y}(\mathrm{NO})(28-34 \%)$ in comparison to the other PA concentrations (Fig. 1F). Leaves of plants sprayed with PA solutions displayed visible necrotic lesions at 48 hai, but only at concentrations $\geq 0.3 \mathrm{mg} \mathrm{PA} \mathrm{ml}^{-1}$ (Fig. S1). The imaging of the $F_{\mathrm{v}} / F_{\mathrm{m}}$, $\mathrm{Y}(\mathrm{NO})$ and $q_{\mathrm{P}}$ parameters became more pronounced (seen as larger necrotic lesions) with increasing PA concentrations (Fig. S1).

\section{Histochemical localization of $\mathrm{H}_{2} \mathrm{O}_{2}$ and $\mathrm{O}_{2}{ }^{\bullet-}$ on leaves sprayed with different PA concentrations}

The deposition of $\mathrm{H}_{2} \mathrm{O}_{2}$ and $\mathrm{O}_{2}{ }^{-\boldsymbol{}}$ at 24 hai on the leaves was stronger as the concentrations of PA increased from 0.3 to $5.0 \mathrm{mg} \mathrm{ml}^{-1}$. The brown and blue colors were less remarkable on the leaves of plants sprayed with $0.1 \mathrm{mg}$ $\mathrm{PA} \mathrm{ml}{ }^{-1}$ resembling the leaves of plants from the control treatment (Fig. 2A,B).

\section{In vitro effect of PA on mycelial growth, conidia production and germination}

Mycelial growth, conidia production and germination were not affected by the concentration of $0.1 \mathrm{mg}$ PA $\mathrm{ml}^{-1}$ (Fig. 3A-D). Compared to the control treatment, mycelial growth was reduced by $22 \%$ on PDA media amended with $0.3 \mathrm{mg} \mathrm{PA} \mathrm{ml}^{-1}$ (Fig. 3A), and reduced on OA media amended with $0.1 \mathrm{mg} \mathrm{PA} \mathrm{ml}^{-1}$ (Fig. 3B). Mycelial growth was completely inhibited on PDA media with PA at concentrations above $0.5 \mathrm{mg} \mathrm{m}^{-1}$ (data not shown). Conidia production and germination were significantly reduced by $58 \%$ on OA media amended with $0.3 \mathrm{mg} \mathrm{PA} \mathrm{ml}^{-1}$ compared to the control treatment. Mycelia growth, conidia production and germination were not affected by the concentration of $0.1 \mathrm{mg} \mathrm{PA} \mathrm{m}^{-1}$ (Fig. 3A-D).

\section{Blast severity}

BS significantly decreased by 59 and $23 \%$ at 72 and 96 hai, respectively, for plants sprayed with PA compared to non-sprayed plants (Fig. 4A). Many necrotic lesions with intense chlorosis and coalescence were noticed on leaves of plants non-sprayed with PA. By contrast, the number and size of the necrotic lesions were reduced, the quantity of coalescing lesions was less, and chlorosis was reduced on leaves of plants sprayed with PA (Fig. 4B). 


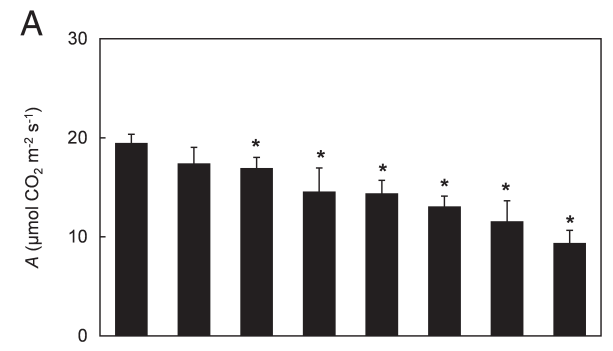

B

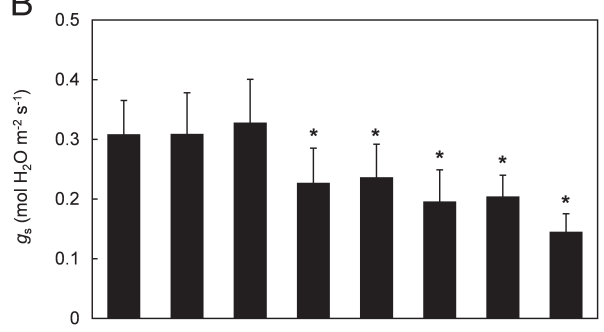

C

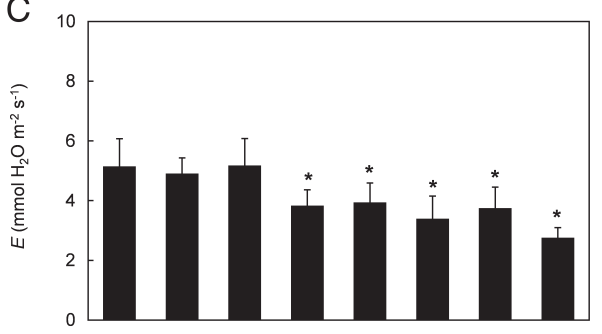

E

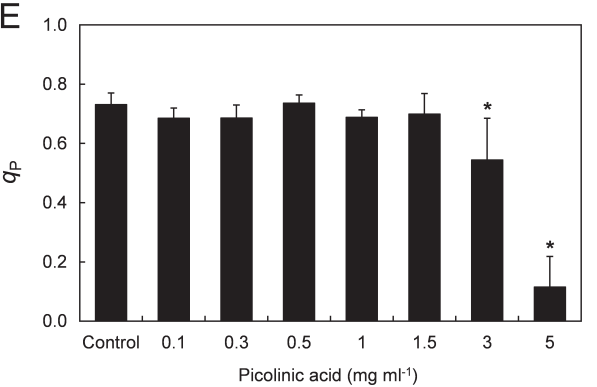

D

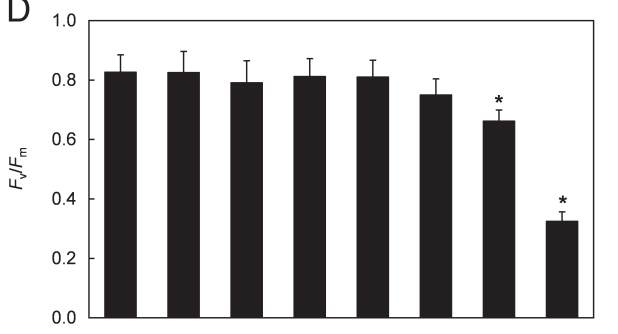

$\mathrm{F}$

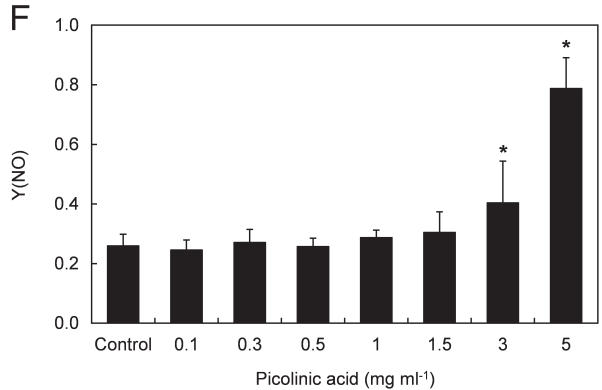

Fig. 1. Leaf gas exchange [net carbon assimilation rate $(A)$, stomatal conductance to water vapor $\left(g_{s}\right)(B)$, and transpiration rate $(E)(C)$ ] and chlorophyll a fluorescence [maximum PSII quantum efficiency $\left(F_{\mathrm{v}} / F_{\mathrm{m}}\right)$ (D), photochemical quenching coefficient $\left(q_{p}\right)(E)$, and yield of non-regulated dissipation energy $(\mathrm{Y}(\mathrm{NO}))(\mathrm{F})$ ] parameters determined at 48 hours after the spray of wheat leaves with water (control) and with picolinic acid (PA) at different concentrations. Mean for each PA concentration with an asterisk (*) differ significantly $(P \leq 0.05)$ from the control treatment according to Dunnet's test. Bars represent the standard deviation of the means from two pooled experiments. $n=10$.
Histochemical localization of $\mathrm{H}_{2} \mathrm{O}_{2}$ and $\mathrm{O}_{2}{ }^{\bullet-}$ on infected leaves sprayed with a non-phytotoxic PA concentration

The production of $\mathrm{H}_{2} \mathrm{O}_{2}$ and $\mathrm{O}_{2}{ }^{--}$was greater on leaves of plants from the $-\mathrm{PA} /+\mathrm{Po}_{0}$ treatment than plants from the $+\mathrm{PA} /+\mathrm{PO}_{O}$ treatment especially at 72 hai (Fig. 5).

\section{Enzyme activities and MDA concentration}

The activities of SOD and APX at 48 hai $(22$ and 24\%, respectively), GR at 48 and 72 hai (24 and 26\%, respectively), CAT at 96 hai $(46 \%)$, and GPX and GST at 48 hai (45 and $52 \%$, respectively) significantly decreased for the $+\mathrm{PA} /-\mathrm{Po}_{\mathrm{O}}$ treatment in comparison to the $-\mathrm{PA} /-\mathrm{Po}_{\mathrm{O}}$ treatment (Fig. 6A-D,F,G). There were significant increases for SOD (120\%), GR (208\%), APX (136\%), POX (145\%) and GST $(134 \%)$ activities at 48 hai, for CAT activity at 96 hai $(99 \%)$ and for GPX activity at 48,72 and 96 hai $(242,45$ and 95\%, respectively), but significant decrease for CAT activity at 72 hai $(50 \%)$ for the $+\mathrm{PA} /+P O$ treatment in comparison to the $-\mathrm{PA} /+P_{O}$ treatment (Fig. 6A-G). For the $-\mathrm{PA} /+P$ o treatment, there were significant increases at 48, 72 and 96 hai for SOD (20,
45 and $41 \%$, respectively), CAT (396, 289 and 58\%, respectively) and POX (197, 300 and $342 \%$, respectively) activities and for APX at 72 and 96 hai (48 and 29\%, respectively) in comparison to the $-\mathrm{PA} /-\mathrm{Po}_{0}$ treatment (Fig. $6 \mathrm{~A}, \mathrm{C}, \mathrm{D}$ and $\mathrm{E}$ ). For the $+\mathrm{PA} /+P o$ treatment, there were significant increases at 48 and 96 hai for SOD (201 and 130\%, respectively), GR (310 and 69\%, respectively) and APX (138 and 58\%, respectively) activities, at 48, 72 and 96 hai for CAT $(121,193$ and $477 \%$, respectively) and POX (854, 270 and $469 \%$, respectively) activities and for GPX (116\%) and GST (228\%) activities at 48 hai in comparison to the $+\mathrm{PA} /-P_{0}$ treatment (Fig. 6A-G). GR activity significantly decreased at 72 hai $(41 \%)$ for the $+\mathrm{PA} /+\mathrm{Po}_{\mathrm{O}}$ treatment in comparison to the treatment $+\mathrm{PA} /-\mathrm{PO}_{\mathrm{O}}$ while GPX significantly decreased at 48,72 and 96 hai $(65,43$ and $23 \%$, respectively) for the $-\mathrm{PA} /+P_{O}$ treatment in comparison to the $-\mathrm{PA} /-P_{0}$ treatment (Fig. $6 \mathrm{~B}$ and F). The MDA concentration was significantly lower for plants from the $+\mathrm{PA} /+P_{O}$ in comparison to those from the $-\mathrm{PA} /+\mathrm{Po}_{\mathrm{O}}$ treatment, but significantly higher at 48 hai $(36 \%)$ for plants from the treatment $+\mathrm{PA} /+\mathrm{PO}_{0}$ in comparison to the treatment $+\mathrm{PA} /-\mathrm{Po}_{\mathrm{O}}$ and at 96 hai $(132 \%)$ for the treatment $-\mathrm{PA} /+P o$ in comparison to the treatment $-\mathrm{PA} /-\mathrm{Po}_{\mathrm{O}}$ (Fig. $6 \mathrm{H}$ ). 

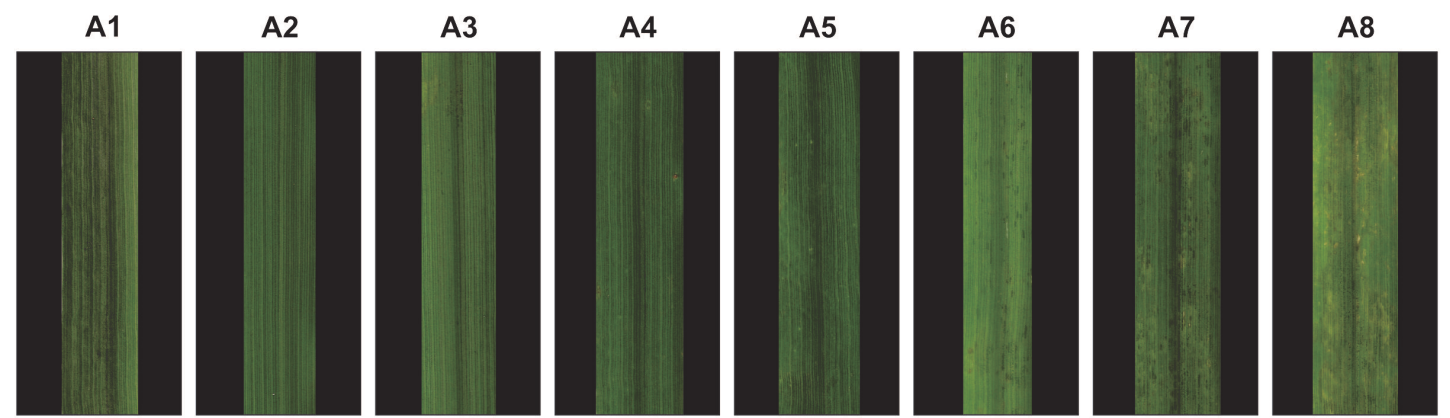

A9

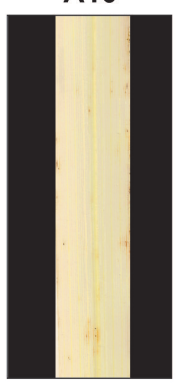

A11

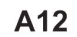

A13

A14

A15

A16
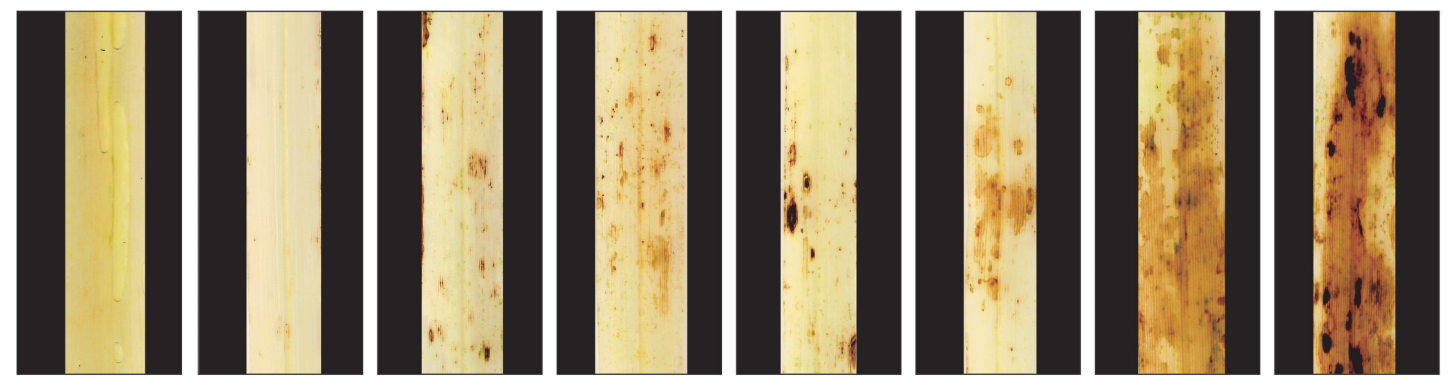

Control

0.3

0.5

1.0

1.5

3.0

5.0

Picolinic acid $\left(\mathrm{mg} \mathrm{ml}^{-1}\right)$

B1

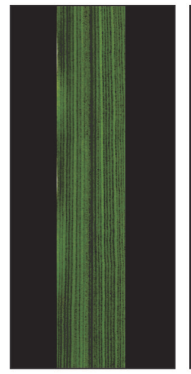

B9

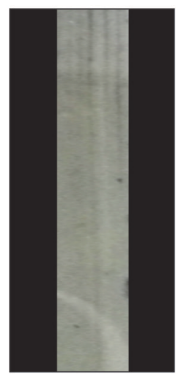

Control
B2

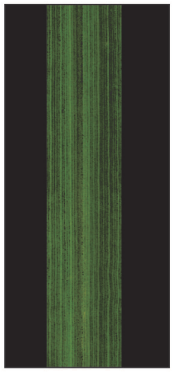

B10

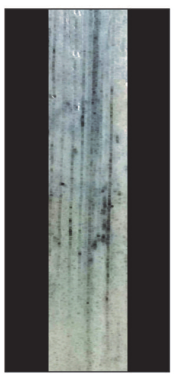

0.1
B3

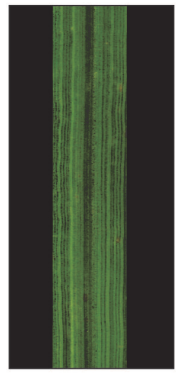

B11

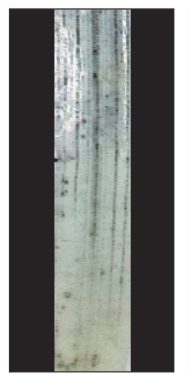

0.3
B4

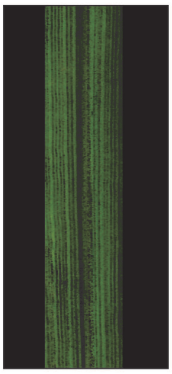

B12

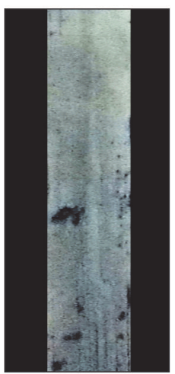

0.5
B5

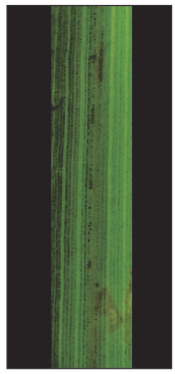

B13

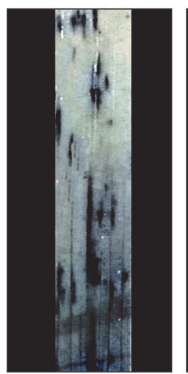

1.0
B6

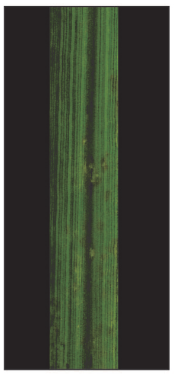

B14

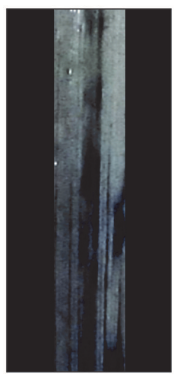

1.5
B7

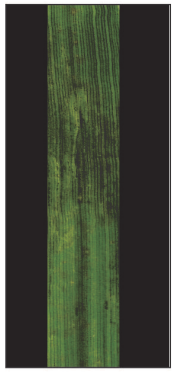

B15

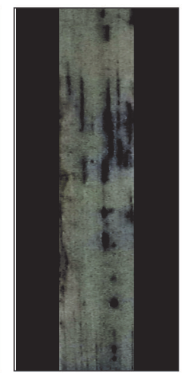

3.0
B8

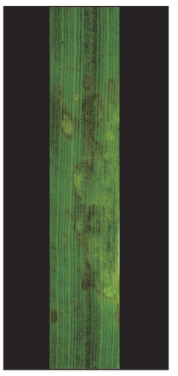

B16

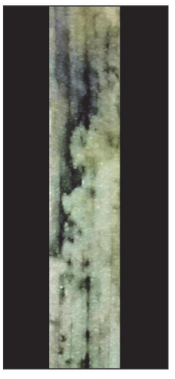

5.0

Picolinic acid $\left(\mathrm{mg} \mathrm{ml}^{-1}\right)$

Fig. 2. Lesion development on the leaves of plants at 24 hours after the spray of picolinic acid at different concentrations (A2-A8 and B2-B8). Leaves of plants at 24 hours after spray with water (A1 and B1) served as the control treatment. These leaves were used for the histochemical detection of hydrogen peroxide $\left[\mathrm{H}_{2} \mathrm{O}_{2}\right](\mathrm{A9}-\mathrm{A} 16)$ and superoxide anion radical $\left[\mathrm{O}_{2}{ }^{--}\right](\mathrm{B} 9-\mathrm{B} 16)$ as indicated by the brown and blue colors, respectively. $\mathrm{n}=15$. 

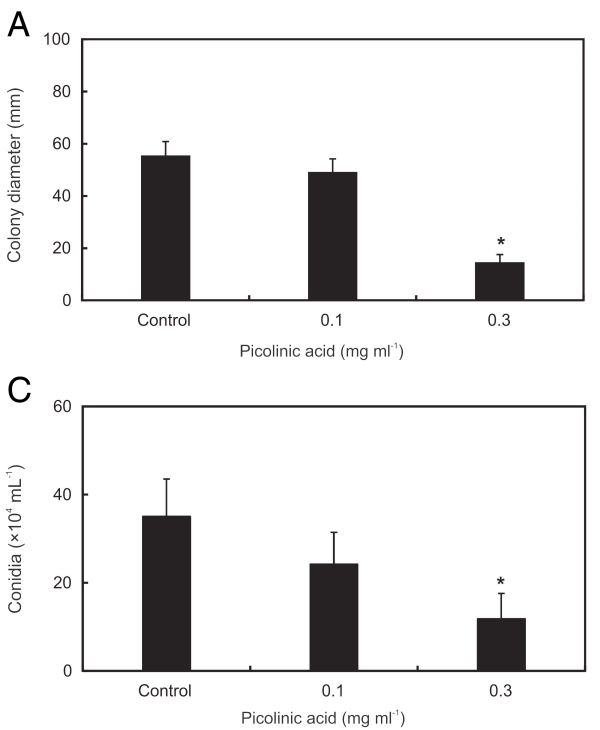

A

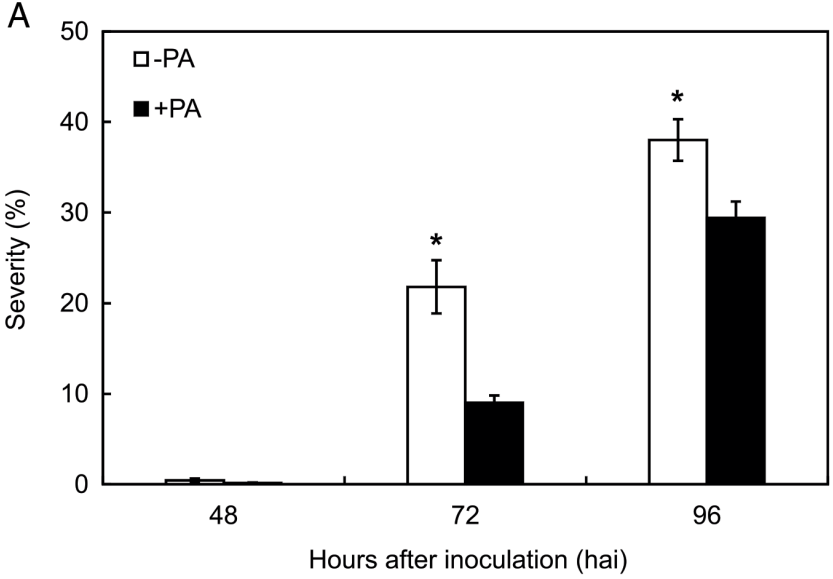

Effect of a non-phytotoxic PA concentration and infection by $P$. oryzae on leaf gas exchange and $\mathrm{Chl}$ a fluorescence parameters

At 96 hai, the values of $A, g_{\mathrm{s}}, E, F_{\mathrm{v}} / F_{\mathrm{m}}$ and $\mathrm{Y}(\mathrm{II})$ were significantly higher $(50,54,49,17$ and $57 \%$, respectively) while those for $\mathrm{Y}(\mathrm{NO})(19 \%)$ were significantly lower for the $+\mathrm{PA} /+P_{O}$ treatment in comparison to the $-\mathrm{PA} /+\mathrm{PO}_{O}$ treatment (Fig. $7 A, B, D, E, F$ and $H$ ). There were significantly decreases at $48,72,96$ hai for $A(21,41$ and $31 \%$, respectively) and $F_{\mathrm{v}} / F_{\mathrm{m}}(9,7$ and $12 \%$, respectively), for $g_{\mathrm{s}}(49$ and $51 \%)$ and $E(41$ and $37 \%)$ and at 96 hai for $\mathrm{Y}(\mathrm{NPQ})(41 \%)$ and significant increase for $\mathrm{Y}(\mathrm{NO})(38 \%)$ at 96 hai for the treatment $+\mathrm{PA} /+\mathrm{PO}_{0}$ in comparison to

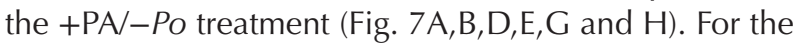
$-\mathrm{PA} /+\mathrm{Po}$ treatment, there were significant decreases at 48,72 , and 96 hai for $A(10,21$, and $63 \%$, respectively) and $F_{\mathrm{v}} / F_{\mathrm{m}}(9,8$ and $32 \%$, respectively), at 72 and 96 hai for $g_{\mathrm{s}}(29$ and $62 \%$, respectively) and $E(22$ and $50 \%$, respectively), and at 96 hai for $\mathrm{Y}(\mathrm{II})(46 \%)$ and $\mathrm{Y}(\mathrm{NPQ})$
Fig. 3. In vitro effect of picolinic acid (PA) at different concentrations on mycelial growth (A and B), conidia production (C) and germination (D). Treatments means followed by an asterisk $\left(^{*}\right)$ are significantly different $(P \leq 0.05)$ according to Dunnet's test. Bars represent the standard desviation of means from two pooled experiments. $\mathrm{n}=8$.

Fig. 4. Severity (A) and blast symptoms development (B) on the leaves of plants sprayed with water (-PA) or sprayed with picolinic acid (PA) (+PA). Means for the -PA and + PA treatments followed by an asterisk (*), at each evaluation time, are significantly different according to $F$ test $(P \leq 0.05)$. Bars represent the standard error of the means from two pooled experiments. $n=10$.
(31\%) while significant increase occurred for $C_{i}$ at 48 $(13 \%)$ and 96 hai $(14 \%)$ and $\mathrm{Y}(\mathrm{NO})$ at 96 hai $(115 \%)$ in comparison to the -PA/-Po treatment (Fig. 6A-H).

Alterations on the images for the $F_{\mathrm{v}} / F_{\mathrm{m}}, \mathrm{Y}(\mathrm{II}), \mathrm{Y}(\mathrm{NPQ})$ and $Y(N O)$ parameters were first noticed at 72 hai mainly on the leaves from plants of the $-\mathrm{PA} /+\mathrm{PO}_{\mathrm{O}}$ treatment compared to $+\mathrm{PA} /+P$ o treatment. Decreases on the $F_{\mathrm{v}} / F_{\mathrm{m}}, \mathrm{Y}(\mathrm{II})$ and $\mathrm{Y}(\mathrm{NPQ})$ values and high $\mathrm{Y}(\mathrm{NO})$ values at 96 hai were closely related to reductions in the light energy dissipassion for the photosynthetic process (black areas in the images) especially on leaves from plants of the $-\mathrm{PA} /+P_{O}$ treatment compared to $+\mathrm{PA} /+P o$ treatment (Fig. S2).

Based on the principal component analysis (PCA) for all treatments at the different evaluation times, the treatments $-\mathrm{PA} /-\mathrm{PO}_{\mathrm{O}}$ and $+\mathrm{PA} /-\mathrm{Po}_{0}$ were kept grouped at 48, 72 and 96 hai (Fig. 8A,C, and E). At 48 hai, the first two PCs accounted for $65 \%$ of the total data variance of the data (PC $1=40 \%$ and PC $2=25 \%$ ) (Fig. $8 \mathrm{~A}$ ). The PC 
Fig. 5. Development of blast lesions on the leaves of plants at 24,48 , and 72 hours after inoculation with Pyricularia oryzae that were nonsprayed (A1-A3 and B1-B3) or sprayed with picolinic acid (A4-A6 and B4-B6). These leaves were used for the histochemical detection of hydrogen peroxide $\left[\mathrm{H}_{2} \mathrm{O}_{2}\right](\mathrm{A} 7-\mathrm{A} 12)$ and superoxide anion radical $\left[\mathrm{O}_{2}^{-}{ }^{-}\right](\mathrm{B} 7-\mathrm{B} 12)$ as indicated by the brown color and blue colors, respectively. $n=15$.
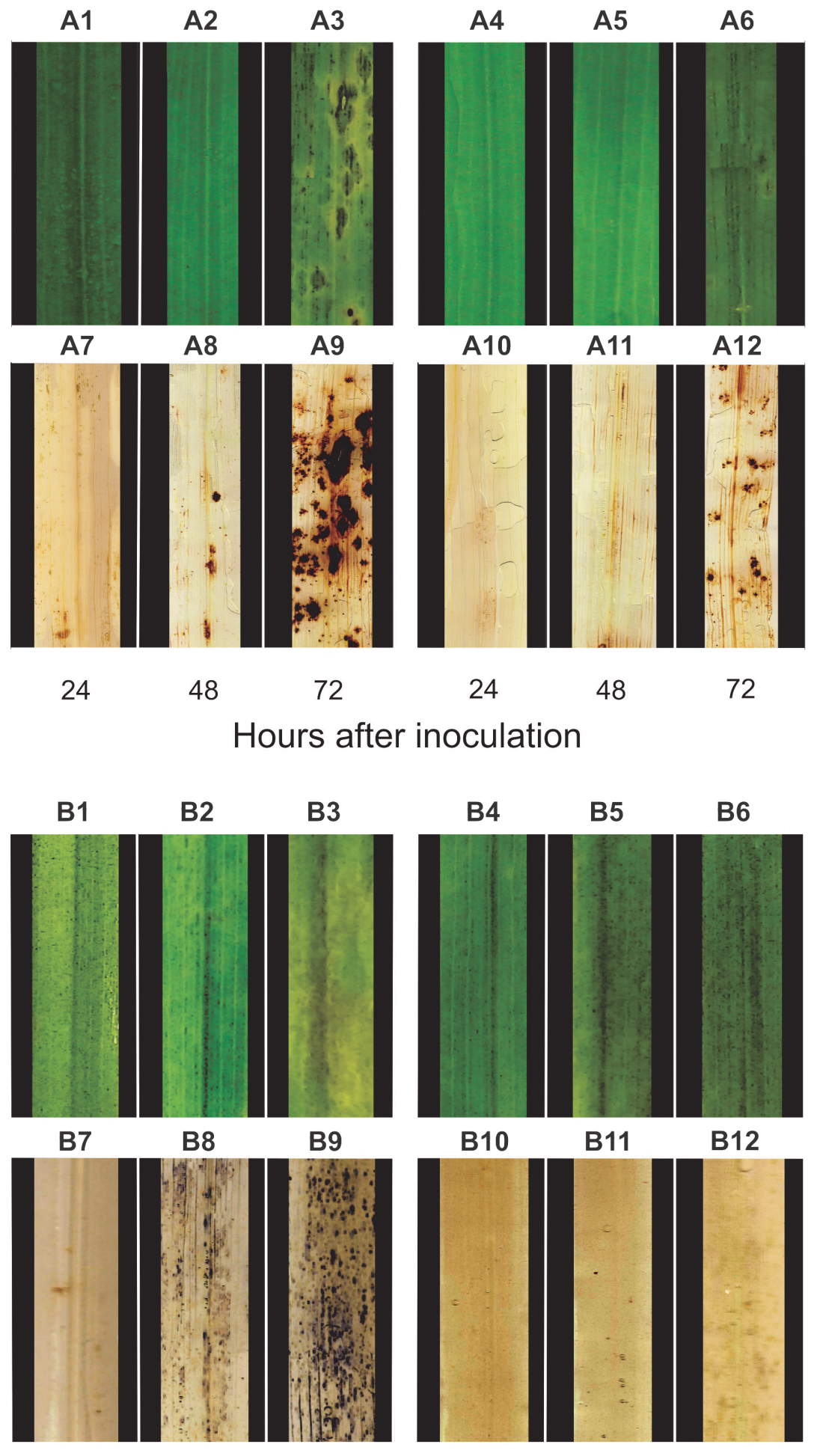

24

48

72

24

48

72

Hours after inoculation 

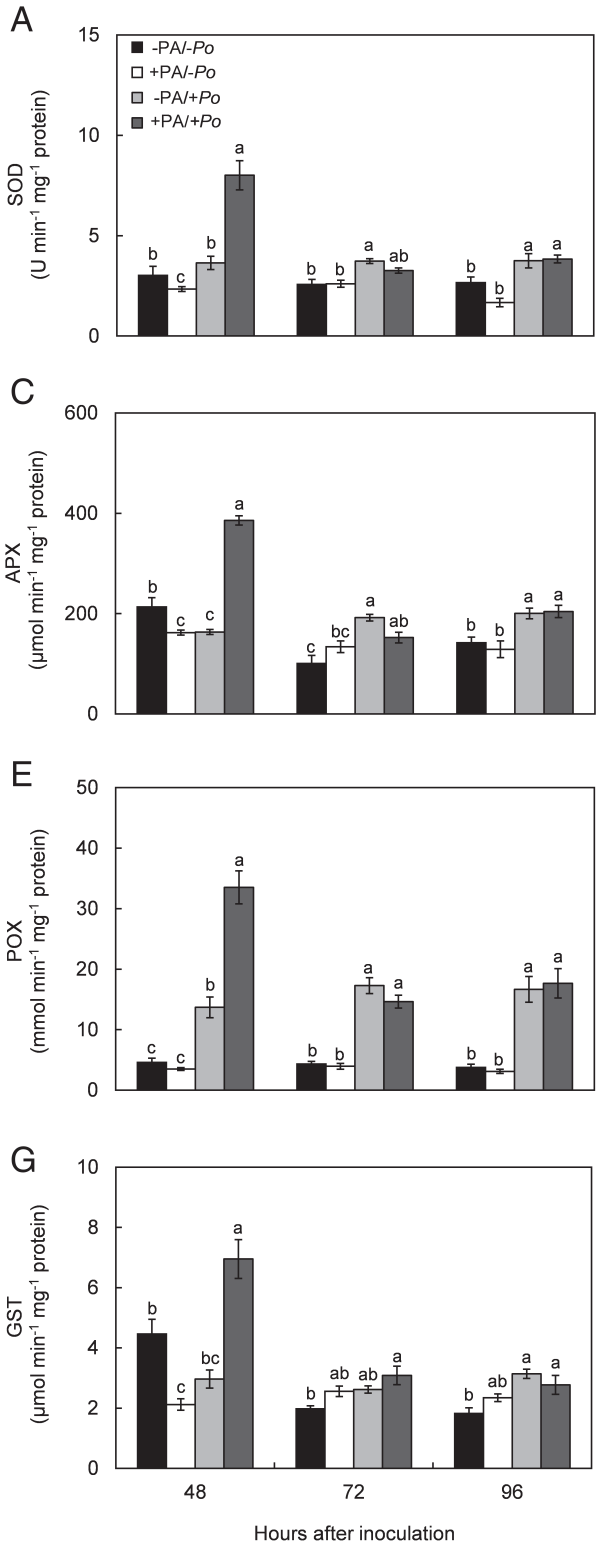
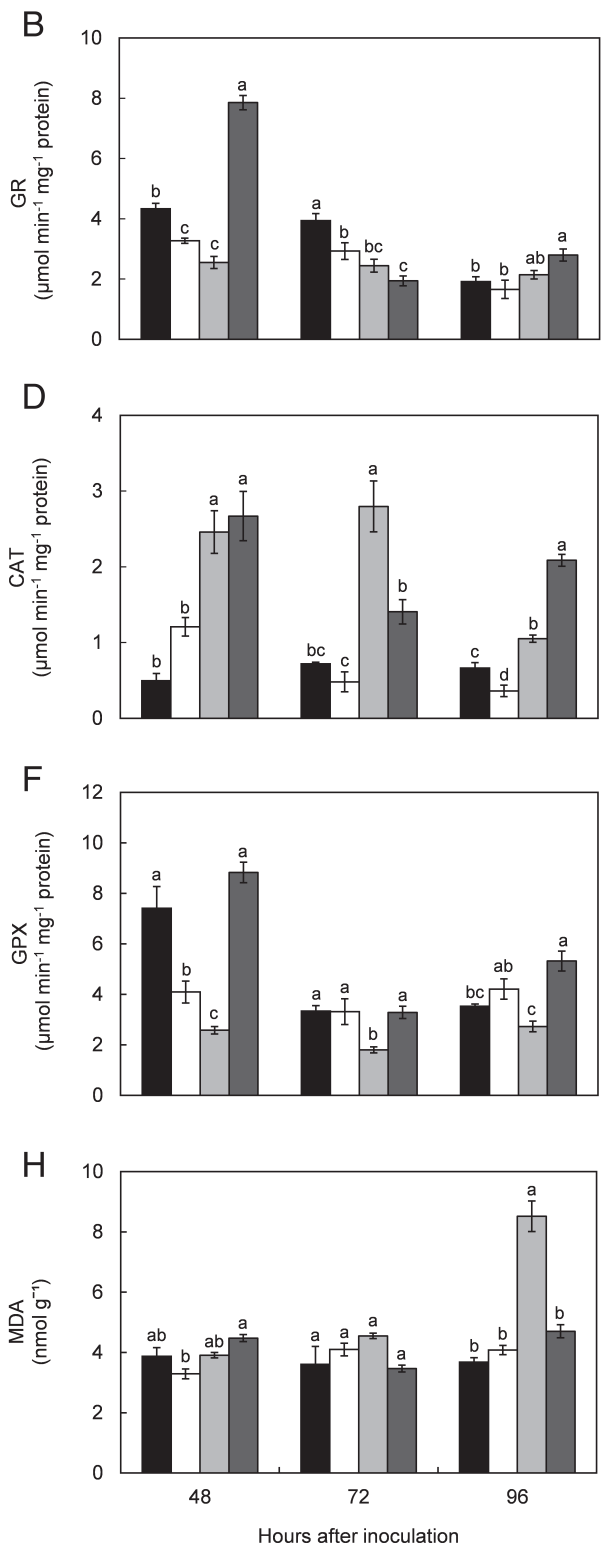

Fig. 6. Activities of superoxide dismutases (SOD) (A), glutathione reductases (GR) (B), ascorbate peroxidases (APX) (C), catalases (CAT) (D), peroxidases (POX) (E), glutathione peroxidases (GPX) (F) and glutathione-S-transferases (GST) (G) as well as concentration of malondialdehyde (MDA) (H) determined in the leaves of wheat plants that were sprayed with water (-PA/-Po), sprayed with $0.1 \mathrm{mg}$ of picolinic acid $(+\mathrm{PA} /-\mathrm{PO}) \mathrm{ml}^{-1}(\mathrm{PA})$, only inoculated with Pyricularia oryzae $(-P A /+P O)$ and sprayed with $0.1 \mathrm{mg} \mathrm{PA} \mathrm{ml}^{-1}$ and inoculated with $P$. oryzae $(+\mathrm{PA} /+P o)$. Means from the treatments followed by different letters are significantly different according to Tukey's test $(P \leq 0.05)$. Bars represent the standard error of the means from two pooled experiments. $n=5$. FW, fresh weight.
1, characterized by positive scores for APX, GST, POX and SOD, showed negative correlations with $F_{\mathrm{v}} / F_{\mathrm{m}}$; the PC 2 showed positive scores for Y(NPQ), GPX and GR and negative correlation with Y(II) (Fig. 8B). At 72 hai, the PCA explained $67 \%$ of the observed variation (PC $1=52 \%$ and PC $2=15 \%$ ) (Fig. 8C). Positive scores for $\mathrm{BS}, \mathrm{POX}$, and SOD and negative correlation between $\mathrm{A}$ and $g_{s}$ parameters were noticed for the PC 1. For PC 2, positive score occurred for $Y($ II) and negative correlations with Y(NPQ), CAT and MDA (Fig. 8D). At 96 hai, 85\% of the total data variance was explained for the two PCs (PC $1=69 \%$ and $\mathrm{PC} 2=16 \%$ ) (Fig. 8E). For PC 1, there were positive scores for $C_{i}, \mathrm{Y}(\mathrm{NO}), \mathrm{BS}, \mathrm{APX}, \mathrm{POX}$, and SOD and negative scores for $A, g_{\mathrm{s}}, E, \mathrm{Y}(\mathrm{II})$ and $F_{\mathrm{v}} / F_{\mathrm{m}}$ (Fig. 8F).
For the $+\mathrm{PA} /+\mathrm{Po}_{\mathrm{O}}$ treatment, the PCA indicated positive correlation with APX, CAT, GR, GPX and GST at 48 and 96 hai. On the other hand, for the $-\mathrm{PA} /+P_{0}$ treatment there were positive correlation for $C_{i}, M D A$ and $Y(N O)$ and negative correlations for $A, g_{\mathrm{s}}, E, \mathrm{Y}(\mathrm{II})$ and $F_{\mathrm{v}} / F_{\mathrm{m}}$.

\section{Discussion}

This study provides, to the best of the authors' knowledge, novel physiological and biochemical evidences that the non-host selective toxin PA improved wheat resistance against $P$. oryzae infection based on the greater efficiency of the antioxidative metabolism as well as reduced losses in the photosynthetic capacity of the infected plants. 
Fig. 7. Net $\mathrm{CO}_{2}$ assimilation rate $(A)(A)$, stomatal conductance to water vapor $\left(g_{\mathrm{s}}\right)(\mathrm{B})$, internal $\mathrm{CO}_{2}$ concentration $\left(C_{\mathrm{j}}\right)$ $(C)$ transpiration rate $(E)(D)$, maximum PSII quantum efficiency $\left(F_{v} / F_{m}\right)(E)$, effective PSII quantum yield $Y(I I)(F)$, quantum yield of regulated energy dissipation Y(NPQ) (G) and quantum yield of non-regulated energy dissipation $\mathrm{Y}(\mathrm{NO})(\mathrm{H})$ determined in the leaves of wheat plants that were sprayed with water $(-P A-P O)$, sprayed with $0.1 \mathrm{mg}$ of picolinic acid (PA) $\mathrm{ml}^{-1}$ (+PA-Po), only inoculated with Pyricularia oryzae $(-P A+P o)$ and sprayed with $0.1 \mathrm{mg} \mathrm{PA} \mathrm{ml}^{-1}$ and inoculated with $P$. oryzae (+PA/-Po). Means from the treatments followed by different letters are significantly different according to Tukey's test $(P \leq 0.05)$. Bars represent the standard error of the means from two pooled experiments. $n=10$.
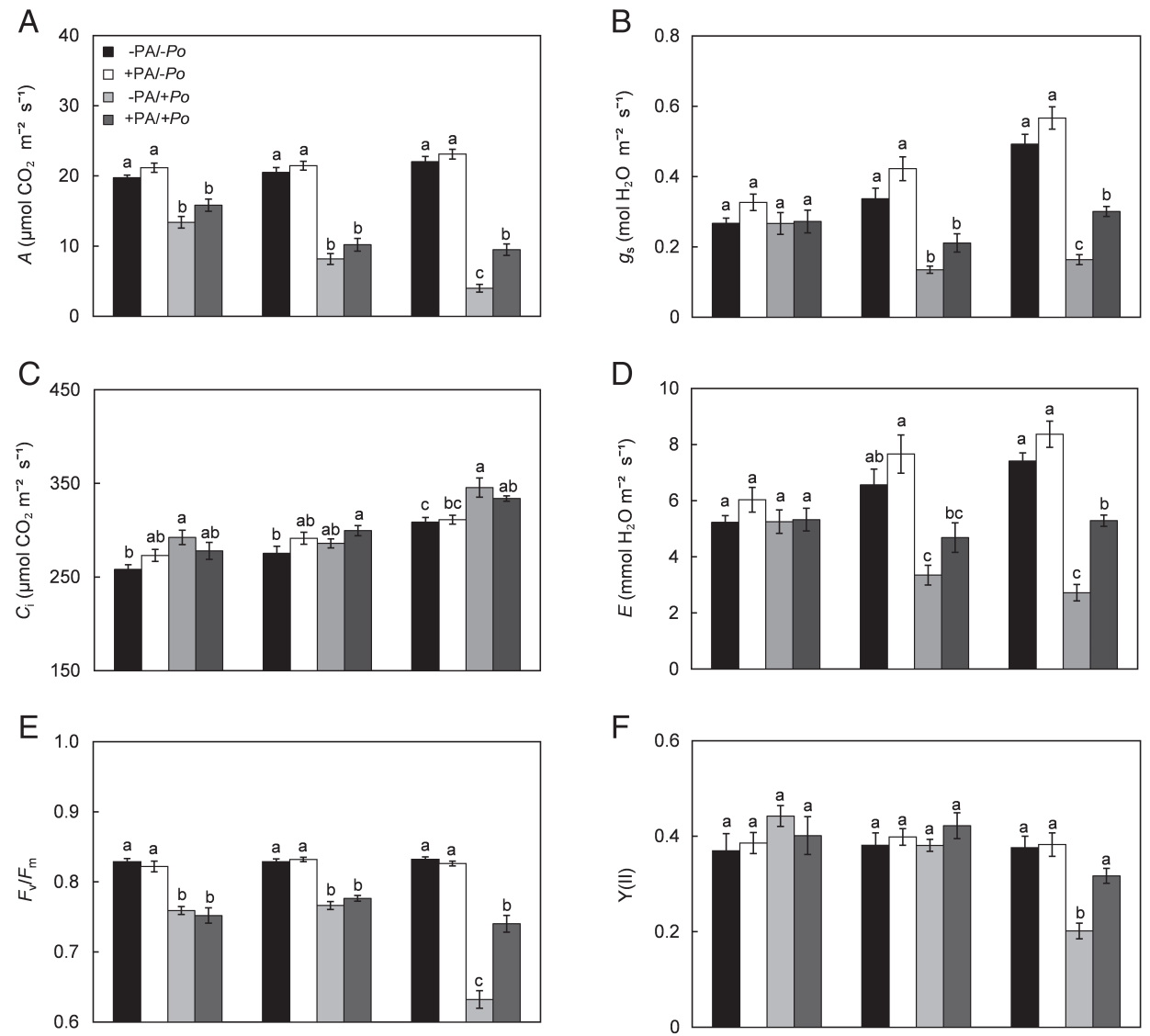

F
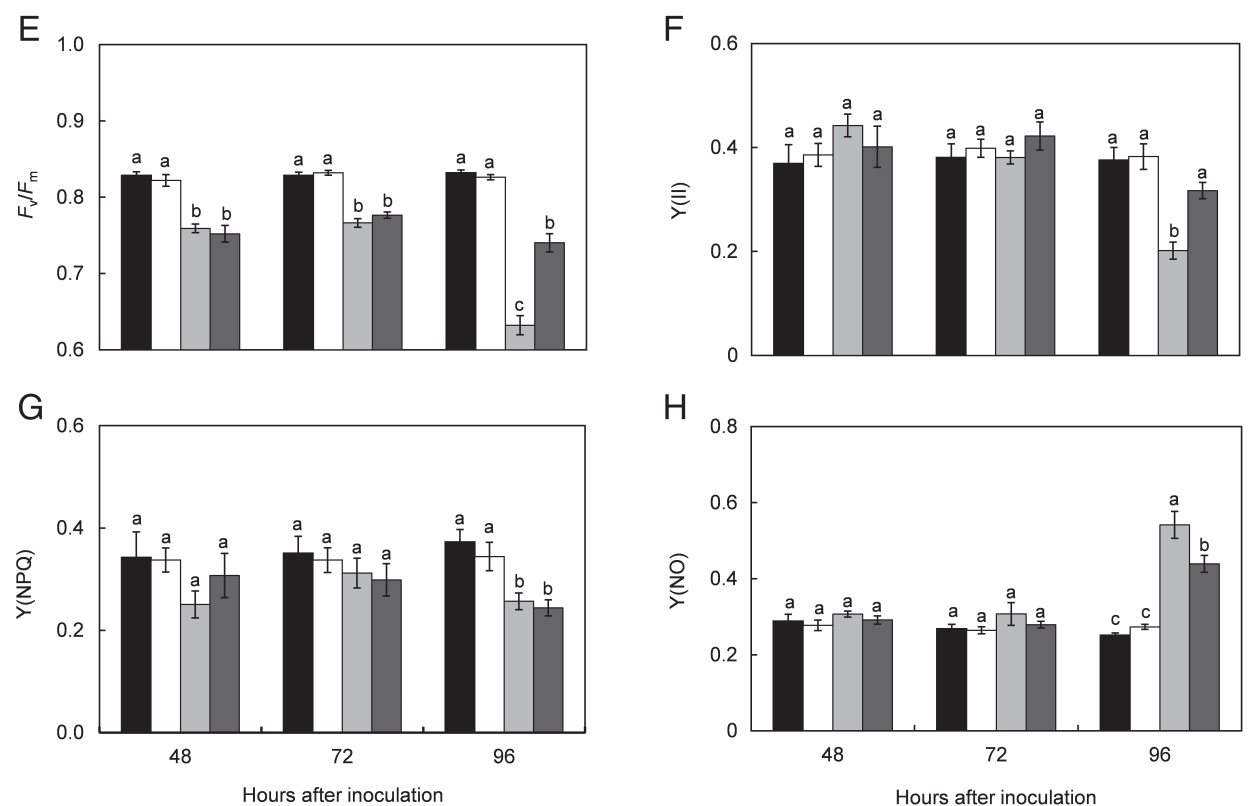

$\mathrm{H}$

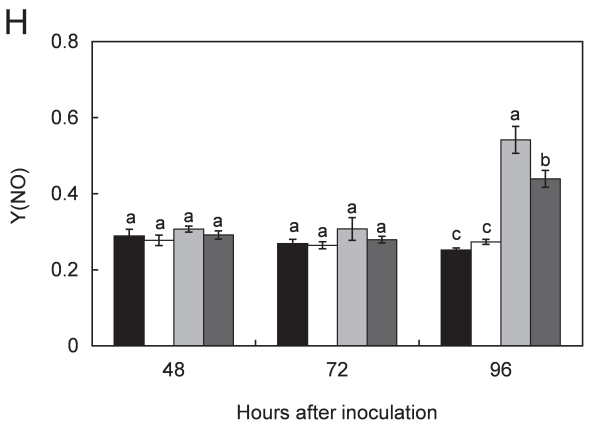

The non-selective host toxins can markedly alter a range of physiological and biochemical processes of plants. For instance, pyricularina, tenuazonic acid, pyriculol as well as the filtrate of $P$. oryzae culture sprayed into rice leaves resulted in the typical blast symptoms besides affecting plant growth (Tamari and Kaji 1959, Umetsu et al. 1972, Singburaudom et al. 1998, Jacob et al. 2016). In this study, necrotic lesions were noticed on wheat leaves at $48 \mathrm{~h}$ after spray with a PA solution. On wheat leaves, the lesions caused by PA were accompanied by the accumulation of $\mathrm{H}_{2} \mathrm{O}_{2}$ and $\mathrm{O}_{2}{ }^{\bullet-}$, being more evident as the concentrations of PA increased. Similar results with $\mathrm{H}_{2} \mathrm{O}_{2}$ were reported in rice leaves sprayed with PA at concentrations starting with $1 \mathrm{mg} \mathrm{ml}^{-1}$ (Zhang et al. 2004).

In this study, the spray of PA solutions caused necrosis of leaf tissues that were accompanied by dramatic reductions in $A$ and $E$ due to diffusive limitations that were linked to lower $g_{\mathrm{s}}$ values. Decreases in photosynthetic gas exchanges associated with toxins have been reported elsewhere, e.g. (1) rapid decreases in $A$ (caused by high concentrations of toxins produced by Helminthosporium maydis) due to stomatal closure associated with limitations in potassium uptake by the guard cells on the corn leaves (Arntzen et al. 1973) and (2) drastic reductions in $g_{\mathrm{s}}$ and $\mathrm{E}$ on the banana leaves caused by fusaric 

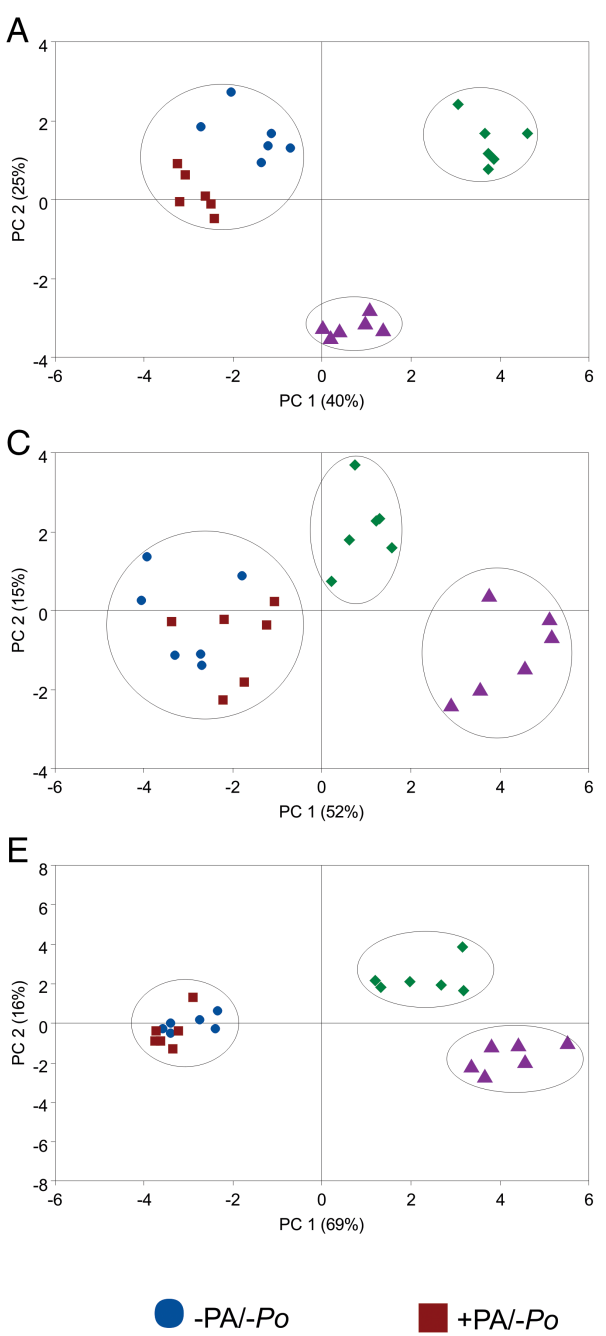

B

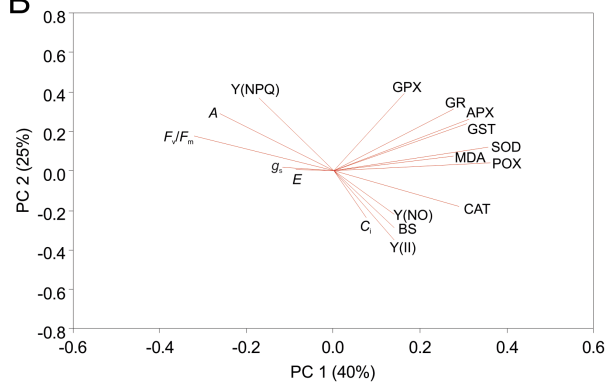

$D_{0}$

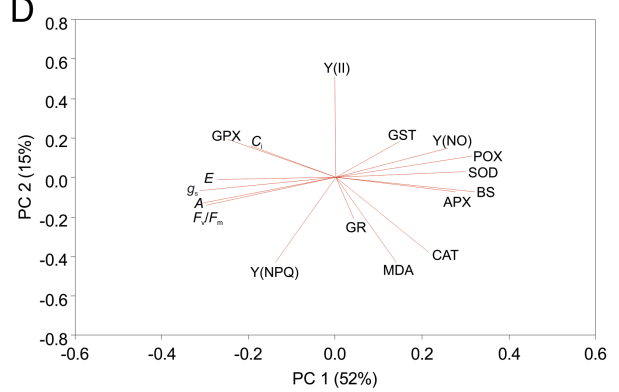

$\mathrm{F}$

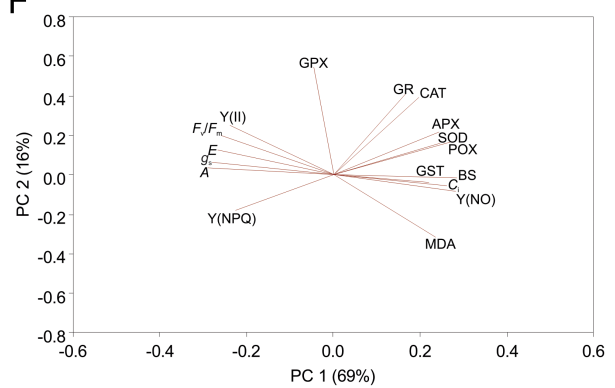

$\Delta-P A /+P O$
Fig. 8. Score plot (A, $C$ and $E$ ) and loading values ( $B, D$ and $F$ ) of principal components analysis comparing blast severity (BS), the leaf gas exchange parameters (net $\mathrm{CO}_{2}$ assimilation rate $[A]$, stomatal conductance to water vapor $\left[g_{\mathrm{s}}\right]$, internal $\mathrm{CO}_{2}$ concentration $\left[C_{\mathrm{i}}\right]$ and transpiration rate $[E])$, chlorophyll fluorescence imaging parameters (maximum PSII quantum efficiency $\left.\left(F_{\mathrm{v}} / F_{\mathrm{m}}\right)\right]$, effective PSII quantum yield $[Y(I I)]$, quantum yield of regulated energy dissipation [Y(NPQ)], and quantum yield of non-regulated energy dissipation $[Y(N O)])$, enzymes of the antioxidant system (superoxide dismutases [SOD], glutathione reductases $[\mathrm{GR}]$, ascorbate peroxidases [APX], catalases [CAT], peroxidases [POX], glutathione peroxidases [GPX] and glutathione-S-transferases [GST]) as well as concentration of malondialdehyde [MDA] determined in the leaves of wheat plants that were sprayed with water (-PA/-Po), sprayed with $0.1 \mathrm{mg}$ of picolinic acid (+PA/-Po) $\mathrm{ml}^{-1}(\mathrm{PA})$, only inoculated with Pyricularia oryzae $(-\mathrm{PA} /+P 0)$, and sprayed with $0.1 \mathrm{mg} \mathrm{PA} \mathrm{\textrm {ml } ^ { - 1 }}$ and inoculated with $P$. oryzae $(+\mathrm{PA}+\mathrm{PO})$ at 48 (A and $\mathrm{B}), 72$ (C and $D$ ) and 96 ( $E$ and $F$ ) hours after inoculation. acid (a non-host selective toxin produced by all Fusarium species) at a concentration of $200 \mathrm{~g} \mathrm{ml}^{-1}$ (Dong et al. 2012). We additionally showed that impairments to photosynthesis caused by PA were also associated with photochemical constraints as denoted by the reductions in both $F_{\mathrm{v}} / F_{\mathrm{m}}$ and $q_{\mathrm{p}}$ that were accompanied by increases in $\mathrm{Y}(\mathrm{NO})$, which altogether indicate damage to the PSII photochemistry. Based on these results, the indirect or direct effects of exogenous PA spray to wheat leaves and further inoculation with $P$. oryzae were next tested.

Based on the in vitro tests, fungal mycelial growth, conidia production and germination were affected by PA suggesting, therefore, that this non-host selective toxin interfered on fungal physiology. In this regard, Pasechnik et al. (1993) demonstrated that concentrations ranging from 0.12 to $0.37 \mathrm{mg} \mathrm{PA} \mathrm{ml}^{-1}$ caused a drastic decrease on conidial germination of $P$. oryzae. Although the

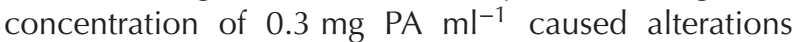
in the pattern of fungal growth, fungal sporulation and conidial germination, this concentration was not selected due to the photosynthetic alterations and the occurrence of necrotic lesions.

A more effective antioxidative metabolism of the plants sprayed with PA, mainly for the enzymes related to the $\mathrm{H}_{2} \mathrm{O}_{2}$ metabolism, enhanced their resistance to blast. This suggests alterations in cellular homeostasis due to high production of ROS associated with host defense responses and the restoration of cellular oxidative balance in agreement with the findings of Torres (2010) and Torres et al. (2006). Additionally, this response was more pronounced for plants sprayed with a solution of $0.1 \mathrm{mg} \mathrm{PA} \mathrm{ml}^{-1}$, especially for SOD, APX, GR, POX, GPX and GST activities at 48 hai, which suggests that different ROS detoxification pathways were operating in response to $\mathrm{PA}$ spray. Therefore, PA favored a more efficient antioxidant metabolism of the infected plants as denoted through the less accumulation of $\mathrm{H}_{2} \mathrm{O}_{2}$ and $\mathrm{O}_{2}{ }^{\bullet-}$. Previous 
studies have shown that an efficient antioxidant system, especially based on the high activities of APX, POX, SOD and GST involved in the removal of ROS, limited cell damages caused by $P$. oryzae infection on wheat leaves, thus contributing to a reduced blast severity (Debona et al. 2012).

This results reinforce the importance of APX and SOD as the major ROS-scavenging enzymes and that a balance on their activities is of paramount importance to determine the state of $\mathrm{H}_{2} \mathrm{O}_{2}$ and $\mathrm{O}_{2}{ }^{\bullet-}$ scavenging (Asada and Takahashi 1987, Bowler et al. 1992, Willekens et al. 1997). Other enzymes also played a role in scavenging ROS, as was the case of CAT, whose activity was higher for inoculated plants regardless of PA spray indicating its importance for the ROS metabolism. Interestingly, CAT activity increased on wheat plants sprayed with abscisic acid, salicylic acid, calcium or $\mathrm{H}_{2} \mathrm{O}_{2}$ (Agarwal et al. 2005). The POX, another enzyme involved in the antioxidant system of plants infected by pathogens (Milavec et al. 2001), was the one that showed the greatest increase throughout fungal infection $(+\mathrm{PA} /+\mathrm{PO}$ and $-\mathrm{PA} /+\mathrm{PO}$ treatments) compared to the non-inoculated plants. Similar results were reported for the Cucurbita pepo-zucchini yellow mosaic virus interaction using the salicylic acid as a plant inducer (Radwan et al. 2007). The GPX and GST, which use GSH to reduce $\mathrm{H}_{2} \mathrm{O}_{2}$ and other hydroperoxides (Noctor et al. 2002, Gill and Tuteja 2010), displayed increased activities during the early stage of $P$. oryzae infection on plants sprayed with PA. According to Debona et al. (2012), GST activity was considered the most important antioxidant enzyme on wheat cultivars resistant to blast. Therefore, it is tempting to suggest that GPX and GST played a key role in increasing wheat resistance to blast mediated by PA through the removal of $\mathrm{H}_{2} \mathrm{O}_{2}$ and, consequently, reducing lipid peroxidation. The GR, a typically chloroplastidic enzyme, plays an essential role in the plant defense system against ROS by sustaining the reduced status of GSH (Gill and Tuteja 2010); it displayed a high activity at 48 hai for plants submitted to the $+\mathrm{PA}+\mathrm{Po}_{\mathrm{O}}$ treatment, suggesting a possible effect of PA in protecting cells against oxidative damage by sustaining a high GSH/GSSG ratio. In some plant-pathogen interactions, GR activity, in addition to controlling the $\mathrm{H}_{2} \mathrm{O}_{2}$ concentration, contributes to avoid lesion expansion, accumulation of salicylic acid, activation of genes related to pathogenesis and signaling pathways of ethylene and jasmonic acid (Mhamdi et al. 2010). Most importantly, the orchestrated action of the antioxidative system of wheat plants sprayed with PA proved to be successful to counteract fungal infection as judged from the lower MDA concentration, which suggests a reduction of cell damage caused by the oxidative stress.
The gas exchange and $\mathrm{Chl}$ a fluorescence imaging parameters were virtually uncompromised on infected wheat plants sprayed with PA in contrast to the dramatic alterations on their values on leaves of non-sprayed plants. All of these findings are consistent with Debona et al. (2014), who reported that the efficient antioxidant metabolism of wheat plants from a cultivar partially resistant to blast was strongly associated with their better photosynthetic performance during $P$. oryzae infection.

The infection of leaves by pathogens often decreases $g_{\mathrm{s}}$ that in turn lead to increased resistance to $\mathrm{CO}_{2}$ diffusion from the atmosphere into the leaf (Erickson et al. 2003, Resende et al. 2012, Aucique-Pérez et al. 2014, Bispo et al. 2014). In this study, $g_{s}$ and $E$ were drastically reduced coupled with increments in $C_{\mathrm{i}}$ for inoculated plants in comparison to the non-inoculated ones. However, the greatest impact of $P$. oryzae occurred in $g_{s^{\prime}} C_{\mathrm{i}}$ and $E$ for plants non-sprayed with PA. In the leaves of wheat plants infected with $P$. oryzae, reduction A was associated with dysfunctions at the level of the biochemical reactions involving $\mathrm{CO}_{2}$ fixation (Debona et al. 2014).

The imaging of the $\mathrm{Chl}$ a fluorescence parameters showed that the non-sprayed leaves with PA were more affected by $P$. oryzae infection than their sprayed counterparts. The $F_{\mathrm{v}} / F_{\mathrm{m}}, \mathrm{Y}(\mathrm{II}), \mathrm{Y}(\mathrm{NPQ})$ and $\mathrm{Y}(\mathrm{NO})$ can increase or decrease as reported for the pathosystems Arabidopsis thaliana-Pseudomonas syringae (Bonfig et al. 2006), coffee-Hemileia vastatrix (Honorato et al. 2015), maize-Stenocarpella macrospora (Bermúdez-Cardona et al. 2015a, 2015b) and rice-Monographella albescens (Tatagiba et al. 2014). Decreases in $F_{\mathrm{v}} / F_{\mathrm{m}}$ on plants infected by pathogens indicate damage to the reactions at the PSII level (Baker 2008). Additionally, reductions in $Y(I I)$ and $Y(N P Q)$ coupled with an increase in $Y(N O)$ at 96 hai for infected plants non-sprayed with PA in contrast to their sprayed counterparts indicated that the ability of leaves on the photochemical energy conversion was significantly compromised at the necrotrophic phase of $P$. oryzae. Decrease in Y(NPQ) suggest impairments in the dissipation of excess of the energy of excitation at the level of the complex antenna (Su et al. 2017), whereas the increase in $Y(N O)$ suggests that both photochemical energy conversion and protective regulatory mechanisms were inefficient (Bonfig et al. 2006). Taken together, these results suggest that $P$. oryzae infection caused drastic alterations in the photosynthetic machinery of the wheat plants by compromising both the dissipation and photo-protective mechanisms, thus ultimately leading to oxidative stress. Nevertheless, these effects were relieved by an efficient antioxidant metabolism on plants sprayed with PA at the earlier stages of fungal infection. 
The lesions formed on the leaves of plants sprayed with PA, mainly at the highest concentrations, dramatically compromised their photosynthetic performance. However, a low PA concentration unable to impair photosynthesis potentiated the antioxidative metabolism of leaves infected by $P$. oryzae for a rapid removal of the ROS and a less oxidative damage that culminated to an increase on wheat resistance to blast.

Acknowledgements - Profs. Rodrigues and DaMatta thank the National Council for Scientific and Technological Development $(\mathrm{CNPq})$ for their fellowships. Dr. C. E Aucique-Pérez was supporter by the "Programa de Estudante-Convênio de Pós-Graduação" (PEC-PG) from CAPES. This study was supported by grants from CNPq and FAPEMIG to Prof. Rodrigues. This study was financed in part by the Coordenação de Aperfeiçoamento de Pessoal de Nível Superior - Brasil (CAPES) - Finance Code 001. We thank Mr. V. S. Rios and Dr. P. R. Silveira for their technical assistance.

\section{References}

Agarwal S, Sairam RK, Srivastava GC, Tyagi A, Meena RC (2005) Role of ABA, salicylic acid, calcium and hydrogen peroxide on antioxidant enzymes induction in wheat seedlings. Plant Sci 169: 559-570

Anderson JV, Davis DG (2004) Abiotic stress alters transcript profiles and activity of glutathione-S-transferase, glutathione peroxidase, and glutathione reductase in Euphorbia esula. Plant Physiol 120: $421-433$

Anderson D, Prasad K, Stewart R (1995) Changes in isozyme profiles of catalase, peroxidase and glutathione reductase during acclimation to chilling in mesocotyls of maize seedlings. Plant Physiol 109: 1247-1257

Arntzen CJ, Haugh MF, Bobick S (1973) Induction of stomatal closure by Helminthosporium maydis pathotoxin. Plant Physiol 52: 569-574

Asada K, Takahashi M (1987) Production and Scavenging of Active Oxygen in Photosynthesis. In: Kyle DJ, Osmond CB, Arntzen CJ (eds) Photoinhibition. Elsevier, Amsterdam, pp 227-287

Aucique-Pérez CE, Rodrigues FA, Moreira WR, DaMatta FM (2014) Leaf gas exchange and chlorophyll a fluorescence in wheat plants supplied with silicon and infected with Pyricularia oryzae. Phytopathology 104: $143-149$

Aver'yanov AA, Lapikova VP, Lebrun MH (2007) Tenuazonic acid, toxin of rice blast fungus, induces disease resistance and reactive oxygen production in plants. Russ J Plant Physiol 54: 749-754

Baker NR (2008) Chlorophyll fluorescence: a probe of photosynthesis in vivo. Ann Rev Plant Biol 59: 89-113
Beauchamp C, Fridovich I (1971) Superoxide dismutase: improved assays and an assay applicable to acrylamide gels. Anal Biochem 44: 276-287

Berestetski AO (2008) A review of fungal Phytotoxins: from basic studies to practical use. Appl Biochem Microbiol 44: 453-465

Bermúdez-Cardona MB, Wordell-Filho JA, Rodrigues FA (2015a) Leaf gas exchange and chlorophyll a fluorescence in maize leaves infected with Stenocarpella macrospora. Phytopathology 105: 26-34

Bermúdez-Cardona MB, Bispo WMS, Rodrigues FA (2015b) Physiological and biochemical alterations on maize leaves infected by Stenocarpella macrospora. Acta Physiol Plant 37: 158-164

Bispo WMS, Araújo L, Bermudez-Cardona MB, Cacique IS, Rodrigues FA, DaMatta FM (2014) Ceratocystis fimbriata-induced changes in the antioxidative system of mango cultivars. Plant Pathol 64: 627-663

Bonfig KB, Schreiber U, Gabler A, Roitsch T, Berger S (2006) Infection with virulent and avirulent $P$. syringae strains differentially affects photosynthesis and sink metabolism in Arabidopsis leaves. Planta 225: 1-12

Bowler C, Montagu MV, Inzé D (1992) Superoxide dismutases and stress tolerance. Annu Rev Plant Physiol Plant Mol Biol 43: 83-116

Bradford MN (1976) A rapid and sensitive method for the quantitation of microgram quantities of protein utilizing the principle of protein-dye binding. Anal Biochem 72: 248-254

Cakmak L, Horst WJ (1991) Effect of aluminum on lipid peroxidation, superoxide dismutase, catalase, and peroxide activity in root tip of soybean (Glycine max). Plant Physiol 83: 463-468

Cakmak I, Marschner H (1992) Magnesium deficiency and high light intensity enhance activities of superoxide dismutase, ascorbate peroxidase and glutathione reductase in bean leaves. Plant Physiol 98: 1222-1227

Carlberg C, Mannervik B (1985) Glutathione reductase. Methods Enzymol 113: 488-495

Castroagudín VL, Ceresini PC, Oliveira SC, Reges JTA, Maciel JLN, Bonato ALV, Dorigan AF, McDonald B (2015) Resistance to Qol fungicides is widespread in Brazilian populations of the wheat blast pathogen Magnaporthe oryzae. Phytopathology 104: 284-294

Chance B, Maehley AC (1955) Assay of catalases and peroxidases. Methods Enzymol 2: 764-775

Chen S, Kang Y, Zhang M, Wang X, Strasser RJ, Zhou B, Qiang S (2014) Differential sensitivity to the potential bioherbicide tenuazonic acid probed by the JIP-test based on fast chlorophyll fluorescence kinetics. Environ Exp Bot 112: 1-15

Cruz MFA, Prestes AM, Maciel JLN, Scheeren PL (2010) Resistência parcial à brusone de genótipos de trigo comum e sintético nos estádios de planta jovem e de planta adulta. Trop Plant Pathol 35: 24-31 
Cruz CD, Peterson GL, Bockus WW, Kankanala P, Dubcovsky J, Jordan KW, Akhunov E, Chumley F, Baldelomar FD, Valent B (2016) The 2NS translocation from Aegilops ventricosa confers resistance to the Triticum pathotype of Magnaporthe oryzae. Crop Sci 56: $1-11$

Daub ME (1986) Tissue culture and the selection of resistance to pathogens. Annu Rev Phytopathol 24: 159-186

Debona D, Rodrigues FA, Rios JA, Nascimento KJT (2012) Biochemical changes in the leaves of wheat plants infected by Pyricularia oryzae. Phytopathology 102: 1121-1129

Debona D, Rodrigues FA, Rios JA, Martins SCV, Pereira LF, DaMatta FM (2014) Limitations to photosynthesis in leaves of wheat plants infected by Pyricularia oryzae. Phytopathology 104: 34-39

Del Longo OT, González CA, Pastori GM, Trippi VS (1993) Antioxidant defences under hyperoxygenic and hyperosmotic conditions in leaves of two lines of maize with differential sensitivity to drought. Plant Cell Physiol 34: 1023-1028

Dong X, Ling N, Wang M, Shen Q, Gou S (2012) Fusaric acid is a crucial factor in the disturbance of leaf water imbalance in Fusarium-infected banana plants. Plant Physiol Biochem 60: 171-179

Erickson JE, Stanosz GR, Kruger EL (2003) Photosynthetic consequences of Marssonina leaf spot differ between two poplar hybrids. New Phytol 161: 577-583

Foyer CH, Halliwell B (1976) The presence of glutathione and glutathione reductase in chloroplasts: a proposed role in ascorbic acid metabolism. Planta 133: 21-25

Giannopolitis CN, Ries SK (1977) Superoxide dismutases I. Occurrence in higher plants. Plant Physiol 59: 309-314

Gill SS, Tuteja N (2010) Reactive oxygen species and antioxidant machinery in abiotic stress tolerance in crop plants. Plant Physiol Biochem 48: 909-930

Goulart ACP, Sousa PG, Urashima AS (2007) Danos em trigo causados pela infecção de Pyricularia grisea. Summa Phytopathol 33: 358-363

Habig WH, Pabst MJ, Jakoby WB (1974) Glutathione-S-transferases. The first enzymatic step in mercapturic acid formation. J Biol Chem 249: 7130-7139

Heath RL, Packer L (1968) Photoperoxidation in isolated chloroplast. I. Kinetics and stoichometry of fatty acid peroxidation. Arch Biochem Biophys 125: 189-198

Honorato JJ, Zambolim L, Aucique-Pérez CE, Resende RS, Rodrigues FA (2015) Photosynthetic and antioxidative alterations in coffee leaves caused by epoxiconazole and pyraclostrobin sprays and Hemileia vastatrix infection. Pest Biochem Physiol 123: 31-39

Howlett BJ (2006) Secondary metabolite toxins and nutrition of plant pathogenic fungi. Curr Opin Plant Biol 9: $371-375$
Igarashi S, Utiamada CM, Igarashi LC, Kazuma AH, Lopes RS (1986) Pyricularia sp. em trigo. Ocorrência de Pyricularia sp. no Estado do Paraná. Fitopatol Bras 11: 351-352

Iwahashi H, Kawamori H, Fukushima K (1999) Quinolinic acid, alpha-picolinic acid, fusaric acid, and 2,6-pyridinedicarboxylic acid enhance the Fenton reaction in phosphate buffer. Chem Biol Interact 118: $201-215$

Jacob S, Grötsch T, Foster AJ, Schüffler A, Rieger PH, Sandjo LP, Liermann JC, Opatz T, Thines E (2016) Unravelling the biosynthesis of pyriculol in the rice blast fungus Magnaporthe oryzae. Microbiology 163: $541-553$

Kar M, Mishra D (1976) Catalase, peroxidase, and polyphenoloxidase activities during rice leaf senescence. Plant Physiol 57: 315-319

Kim J-C, Min J-Y, Kim H-T, Cho K-Y, Yu S-H (1998) Pyricuol, a new phytotoxin from Magnaporthe grisea. Biosci Biotechnol Biochem 62: 73-74

Kohli MM, Mehta YR, Guzman E, De Viedma L, Cubilla LE (2011) Pyricularia blast - a threat to wheat cultivation.

Czech J Genet Plant 47: 130-134

Kramer DM, Johnson G, Kiirats O, Edwards GE (2004) New fluorescence parameters for the determination of $\mathrm{Q}_{\mathrm{A}}$ redox state and excitation fluxes. Photosynth Res 79: 209-218

Lancashire PD, Bleiholder H, Langelüddecke P, Stauss R, Van Den Boom T, Weber E, Witzenberger A (1991) An uniform decimal code for growth stages of crops and weeds. Annu Appl Biol 119: 561-601

Malaker PK, Barma NCD, Tiwari TP, Collis WJ, Duveiller E, Singh PK, Joshi AK, Singh RP, Braun H-J, Peterson GL, Pedley KF, Farman ML, Valent B (2016) First report of wheat blast caused by Magnaporthe oryzae pathotype triticum in Bangladesh. Plant Dis 100: 2330

Mhamdi A, Queval G, Chaouch S, Vanderauwera S, Van Breusegem F, Noctor G (2010) Catalase function in plants: a focus on Arabidopsis mutants as stress-mimic models. J Exp Bot 61: 4197-4220

Milavec M, Ravnikar M, Kovac M (2001) Peroxidases and photosynthetic pigments in susceptible potato infected with potato virus YNTN. Plant Physiol Biochem 39: $891-898$

Moore KJ, Dixon PM (2015) Analysis of combined experiments revisited. Agron J 107: 763-771

Nagalakshmi N, Prasad MNV (2001) Responses of glutathione cycle enzymes and glutathione metabolism to copper stress in Scenedesmus bijugatus. Plant Sci 160: $291-299$

Nakano Y, Asada K (1981) Hydrogen peroxide is scavenged by ascorbate-specific peroxidase in spinach chloroplasts. Plant Cell Physiol 22: 867-880

Noctor G, Gomez L, Vanacker H, Foyer HC (2002) Interactions between biosynthesis, compartmentation, 
and transport in the control of glutathione homeostasis and signalling. J Exp Bot 53: 1283-1304

Oxborough K, Baker NR (1997) Resolving chlorophyll a fluorescence imaging of photosynthetic efficiency into photochemical and non-photochemical components - calculation of $q_{\mathrm{p}}$ and $F_{\mathrm{v}}{ }^{\prime} / F_{\mathrm{m}}{ }^{\prime}$ without measuring $F_{0}$. Photosynth Res 54: 135-142

Pasechnik TD, Sviridov SI, Aver'yanov AA, Lapikova VP (1993) Picolinic acid toxicity for Pyricularia oryzae Cav. spores and self-inhibition of their germination. Mikol Fitopatol 27: 38-42

Prabhu AS, Rush MC (1997) Differential sensitivity of callus derived from immature panicles of rice cultivars to the non-specific toxin of Pyricularia grisea. Plant Cell Tiss Org 50: 13-18

Radwan DEM, Fayez KA, Mahmoud SY, Hamad A, Lu G (2007) Physiological and metabolic changes of Cucurbita pepo leaves in response to zucchini yellow mosaic virus (ZYMV) infection and salicylic acid treatments. Plant Physiol Biochem 45: 480-489

Resende RS, Rodrigues FA, Cavatte PC, Martins SCV, Moreira WR, Chaves ARM, DaMatta FM (2012) Leaf gas exchange and oxidative stress in sorghum plants supplied with silicon and infected by Colletotrichum sublineolum. Phytopathology 102: 892-898

Rios JA, Debona D, Duarte HSS, Rodrigues FA (2013) Development and validation of a standard area diagram set to assess blast severity on wheat leaves. Eur J Plant Pathol 136: 603-611

Rios JA, Rios VS, Paul PA, Souza MA, Araújo L, Rodrigues FA (2016) Fungicide and cultivar effects on the development and temporal progress of wheat blast under field conditions. Crop Prot 89: 152-160

Singburaudom N, Chaudhary RN, Sommartyal T, Sarobol E (1998) Effects of plant age on symptom development produced by Pyricularia oryzae toxin. Kasetsart J (Nat Sci) 32: 90-101

Su F, Villaume S, Rabenoelina F, Crouzet J, Clément C, Vaillant-Gaveau N, Dhondt-Cordelier S (2017) Different Arabidopsis thaliana photosynthetic and defense responses to hemibiotrophic pathogen induced by local or distal inoculation of Burkholderia phytofirman.

Photosynth Res 134: $201-214$

Tamari K, Kaji J (1959) The accumulation of coumarin in stunted rice plant caused by the ill-effects of piricularin. J Agric Chem Soc Japan 33: 181-183

Tatagiba SD, Rodrigues FA, DaMatta FM (2014) Leaf gas exchange and chlorophyll a fluorescence imaging of rice leaves infected with Monographella albescens. Phytopathology 105: 180-188

Torres MA (2010) ROS in biotic interactions. Physiol Plant 138: $414-429$
Torres MA, Jones JDG, Dangl JL (2006) Reactive oxygen species signaling in response to pathogens. Plant Physiol 141: $373-378$

Tsuge T, Harimoto Y, Akimitsu K, Ohtani K, Kodama M, Akagi Y, Egusa M, Yamamoto M, Otani H (2013) Host-selective toxins produced by the plant pathogenic fungus Alternaria alternata. FEMS Microbiol Rev 37: 44-66

Tsurushima T, Minami Y, Miyagawa H, Nakayashiki H, Tosa Y, Mayama S (2010) Induction of chlorosis, ROS generation and cell death by a toxin isolated from Pyricularia oryzae. Biosci Biotechnol Biochem 74: 2220-2225

Umetsu N, Kaji J, Tamari K (1972) Investigation on the toxin production by several blast fungus strains and isolation of tenuazonicacid as a novel toxin. Agric Biol Chem 36: 859-866

Wheeler H, Luke HH (1963) Microbial toxins in plant disease. Annu Rev Microbiol 17: 223-242

Willekens H, Chamnongpo S, Davey M, Schraudner M, Langebartels C, Montagu MV, Inzé D, Camp WV (1997) Catalase is a sink for $\mathrm{H}_{2} \mathrm{O}_{2}$ and is indispensable for stress defence in $\mathrm{C}_{3}$ plants. EMBO J 16: 4806-4816

Willis DK, Barta TM, Kinscherf TG (1991) Genetics of toxin production and resistance in phytopathogenic bacteria. Experientia 47: 765-771

Wolpert TJ, Dunkle LD, Cuiffetti LM (2002) Host-selective toxins and avirulence determinants: What's in a name? Annu Rev Phytopathol 40: 251-285

Xavier-Filha MS, Rodrigues FA, Domiciano GP, Oliveira HV, Silveira PR, Moreira WR (2011) Wheat resistance to leaf blast mediated by silicon. Australas Plant Pathol 40: 28-38

Yoder OC (1980) Toxins in pathogenesis. Annu Rev Phytopathol 18: 103-129

Zhang H, Zhang X, Mao B, Li Q, He Z (2004) Alpha-picolinic acid, a fungal toxin and mammal apoptosis-inducing agent, elicits hypersensitive-like response and enhances disease resistance in rice. Cell Res 14: 27-33

\section{Supporting Information}

Additional supporting information may be found online in the Supporting Information section at the end of the article.

Fig. S1. Lesions and images of the chlorophyll a fluorescence parameters

Fig. S2. Images of the parameters of chlorophyll a fluorescence 